\title{
Snow accumulation rates in northern Victoria Land, Antarctica, by firn-core analysis
}

\author{
Barbara Stenni, ${ }^{1,3}$ Francesca Serra, ${ }^{1}$ Massimo Frezzotti, ${ }^{2}$ Valter Maggi, ${ }^{3}$ \\ Rita Traversi ${ }^{4}$ Silvia Begagli, ${ }^{4}$ Roberto Udisti ${ }^{4,5}$ \\ ${ }^{1}$ Department of Geological, Environmental and Marine Sciences, University of Trieste, Via E. Weiss 1, I-34127 Trieste, Italy \\ ${ }^{2}$ ENEA CR, Casaccia, P.O. Box 2400, I-00100 Rome, Italy \\ ${ }^{3}$ Department of Environmental Sciences, University of Milan, Piazza della Scienza 1, I-20126 Milan, Italy \\ ${ }^{4}$ Department of Public Health and Environmental Analytical Chemistry, University of Florence, Via Gino Capponi 9, I-50121 Florence, Italy \\ ${ }^{5}$ Department of Chemistry, University of Calabria, I-87030 Arcavacata di Rende (Cosenza), Italy
}

\begin{abstract}
A multiparametric (chemical, isotopic and physical) study on three shallow firn cores sampled in northernVictoria Land was carried out to obtain glaciological information and climatic data in this Antarctic region. Sampling areas were accurately prospected to identify sites, located at different altitudes and distances from the sea, where the snow accumulation was not influenced by katabatic wind redistribution or summer melting. Stratigraphic, isotopic $\left(\delta^{18} \mathrm{O}\right)$ and chemical $\left(\mathrm{H}_{2} \mathrm{O}_{2}, \mathrm{MSA}\right.$ and nssSO $\left.{ }_{4}{ }^{2-}\right)$ profiles were mutually examined for dating purposes and to determine the mean snow-accumulation rates at three different stations. Annual accumulation rates of $85-420 \mathrm{~kg} \mathrm{~m}^{-2} \mathrm{a}^{-1}$ were determined in the period 1971-92. An inverse pattern between accumulation rate and altitude was shown by the progression of the mean annual rates of 160, 203 and $260 \mathrm{~kg} \mathrm{~m}^{-2} \mathrm{a}^{-1}$, respectively, in the highest, medium and lowest stations. The mean accumulation value of all northern Victoria Land data available, $170 \mathrm{~kg} \mathrm{~m}^{-2} \mathrm{a}^{-1}$, represents a decrease of up to $35 \%$ with respect to the estimated value most widely used until now. Our accumulation value is very close to that required for a zero net surface mass balance according to ice discharge. A linear relationship with a gradient of $0.81 \%{ }^{\circ} \mathrm{C}^{-1}$ has been found between mean $\delta^{18} \mathrm{O}$ values and mean annual surface temperature for different ice cores drilled in northern Victoria Land.
\end{abstract}

\section{INTRODUGTION}

Antarctic mass balance has received increased attention because of the ongoing discussion of an enhanced greenhouse effect, where one of the important questions is how the warming would affect the Antarctic ice sheet. Accumulation rate is a fundamental parameter for evaluating the Antarctic mass balance. Spatial and temporal accumulation-rate variability can be obtained from seasonal records of stable isotopes and chemical species in firn and ice core. Firn- and ice-core analysis is also one of the few tools available for studying the environmental and climatic conditions of the Antarctic continent, where meteorological data are scarce.

The aim of this work is to improve knowledge of the snow accumulation-rate distribution in the northern Victoria Land region, for a better understanding of the ice-cap mass balance and the phenomena related to global change in Antarctica. Northern Victoria Land presents varied characteristics: it is a typical coastal region (with sudden and intense transport phenomena on a small scale with a strongly seasonal character), yet it also has plateau-like areas, resulting from the presence of the Transantarctic Mountains at a short distance from the sea, where transport phenomena on a global scale can sometimes be observed (Udisti and others, 1998a). The chemical and physical analyses of firn and ice cores in areas with large altitude variations and very different annual snow accumulations permit the observation of environmental variations over several decades, with detailed analyses of the seasonal behaviour of the main and secondary sources of atmospheric aerosol. Moreover, the evaluation of the snow-accumulation rate can give experimental calibration to satellite measurements of the glacial area mass balance.

For these purposes, shallow firn cores were collected at three stations situated at different altitudes and distances from the sea, to obtain stratigraphic, isotopic $\left(\delta^{18} \mathrm{O}\right)$ and chemical profiles of seasonal markers $\left(\mathrm{H}_{2} \mathrm{O}_{2}\right.$, methanesulphonic acid (MSA) and non-sea-salt sulphate $\left.\left(\mathrm{nssSO}_{4}{ }^{2-}\right)\right)$. The spatial and temporal distribution of these parameters allowed an evaluation of the seasonality and altitude effects on the snow composition. A reliable stratigraphic dating was obtained by critical comparison between the isotopic profile and a new chemical multiparametric profile, obtained using a linear combination of the three above-mentioned seasonal markers.

Stable-isotope stratigraphy has long been successfully used to determine palaeoclimatic conditions in deep ice cores recovered from both Greenland and Antarctica (Dansgaard and others, 1993; Jouzel and others, 1993; Petit and others, 1999), but shorter time periods have also been investigated (Peel and others, 1988; Goodwin, 1991; Mosley-Thompson and others, 1991; Isaksson and Karlén, 1994). The oxygen and hydrogen isotopic composition of polar snow is mainly related to the condensation temperature (Dansgaard, 1964), but conditions prevailing in the source regions (Merlivat and Jouzel, 1979), variation of sea-ice extension (Bromwich and Weaver, 
1983) and seasonal variation in the timing of precipitation events (Steig and others, 1994) can also affect its value.

The temperature dependence of the $\delta$ values implies that the seasonal variations of this parameter are preserved in a $\delta^{18} \mathrm{O}$ (or $\delta \mathrm{D}$ ) record. However snowdrifts and homogenization processes in the firn can affect the original $\delta$ profile. The seasonal $\delta$ amplitude may decrease with depth, due to diffusion processes, which act more effectively in the firn layers when accumulation rates are low (Johnsen, 1977). This is particularly true on moving inland towards the centre of the Antarctic Plateau.

$\mathrm{H}_{2} \mathrm{O}_{2}$ is principally produced in the atmosphere by radical reactions originating from the photolysis of $\mathrm{O}_{3}$. Therefore, the maximum concentration of $\mathrm{H}_{2} \mathrm{O}_{2}$ is found in snow precipitation occurring in the period of maximum solar radiation, from late spring to late summer. The $\mathrm{H}_{2} \mathrm{O}_{2}$ which is contained in the snow can remain stable for long periods of time (Neftel, 1991). In areas with high accumulation rates, where neither wind-redistribution effects nor diffusion by summer melting significantly perturbs the structure of the snowpack, the seasonal variation of $\mathrm{H}_{2} \mathrm{O}_{2}$ content is one of the most reliable chemical methods for sequentially dating successive snow layers (Sigg and others, 1992; Neftel and Fuhrer, 1993; Piccardi and others, 1994a; Udisti, 1996).

The nss $\mathrm{SO}_{4}{ }^{2-}$ found in Antarctic snow is mainly produced by the oxidation of biogenic dimethylsulphide (DMS), volcanic emissions and crustal sources (Delmas, 1986; Legrand and others, 1988; Shaw, 1988). In summer, the main contribution to $\mathrm{nssSO}_{4}{ }^{2-}$ comes from the biogenic DMS (Savoie and Prospero, 1989; Legrand and others, 1991; Delmas, 1994; Saltzman, 1995; Wagenbach, 1996), so the $\mathrm{nsSSO}_{4}{ }^{2-}$ aerosol-concentration maxima are found in the period of phytoplanktonic bloom and in the period immediately after that (January-February).

MSA derives solely from the oxidation of phytoplanktonic DMS, and is therefore an unequivocal marker of biological marine activity (Saltzman and others, 1983, 1986; Legrand and Saigne, 1988; Savoie and Prospero, 1989; Legrand and others, 1991; Udisti and others, 1993; Piccardi and others, 1994a; Legrand, 1995; Saltzman, 1995; Udisti, 1996; Wagenbach, 1996; de Mora and others, 1997). The seasonal trend of MSA is the same as that already seen for $\mathrm{nssSO}_{4}{ }^{2-}$ (same DMS source and similar atmospheric transport processes). MSA summer maxima are often observed in snow (Mulvaney and others, 1993; Udisti and others, 1993; Langway and others, 1994; Piccardi and others, 1996b; Udisti, 1996) and in aerosol (Ayers and Gras, 1991; Ayers and others, 1991; Saltzman, 1995; Wagenbach, 1996; de Mora and others, 1997) measurements. However, some authors (e.g. Mulvaney and others, 1992; Minikin and others, 1994) show a dephasing between $\mathrm{nsSSO}_{4}{ }^{2-}$ and MSA maxima, with MSA maxima occurring also in the winter period, probably due to postdepositional phenomena. In our measurements of snow-pit and shallow firn-core samples in northern Victoria Land, such dephasing was never found; thus, MSA was used, in combination with $\mathrm{nssSO}_{4}{ }^{2-}$, for snow-pit and firn-core dating (Piccardi and others, 1994a; Udisti, 1996).

\section{SAMPLING AREA}

Terra Nova Bay is located in a border area between regions with different physiographic and glaciological characteristics (Fig. 1). The mountains of the Transantarctic Chain of

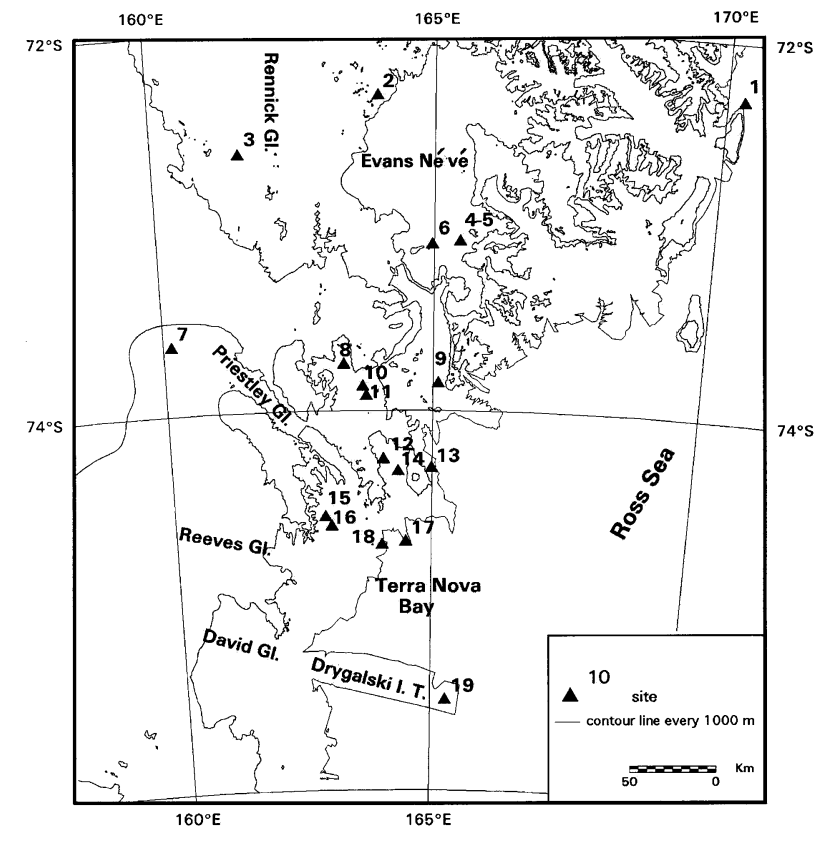

\section{Fig. 1. Sketch map of Victoria Land area. Station numbers} relate to Table 1.

northern Victoria Land, with their alpine glaciers and névé reaching heights of $>3000 \mathrm{~m}$ a.s.l., are located to the north. To the south lie glaciers that drain local nunatak areas and in part the most peripheral area of the ice sheet. The principal outlet glaciers of Victoria Land, David, Reeves and Priestley Glaciers, drain into Terra Nova Bay. These constitute the Nansen Ice Sheet (Priestley and Reeves Glaciers) and the Drygalski Ice Tongue (David Glacier). Terra Nova Bay is one of the regions of Victoria Land where the East Antarctic ice sheet is nearest to the sea (about $75 \mathrm{~km}$ ). The proximity of the ice sheet to the sea and the presence of the outlet glacier valleys are responsible for the confluence of katabatic winds inTerra Nova Bay (Bromwich and Kurtz, 1984). The intensity and persistence of the predominantly wintry katabatic winds create a permanent polynya in the bay.

Information about snow accumulation and mean annual temperatures in the Ross Sea area comes from meteorological, stratigraphic and chemical analyses of snow pits and firn cores and from $10 \mathrm{~m}$ borehole temperatures (Table 1). In the Terra Nova Bay area, mean net accumulation values of about $150 \mathrm{~kg} \mathrm{~m}^{-2} \mathrm{a}^{-1}$ were measured for small local glaciers fed by wind-blown snow, and average ablation values of about $200 \mathrm{~kg} \mathrm{~m}^{-2} \mathrm{a}^{-1}$ were measured for the blue-ice areas (Frezzotti, 1993). The Terra Nova Bay area is located between the surface balance isopleths of 200 and $150 \mathrm{~kg} \mathrm{~m}^{-2} \mathrm{a}^{-1}$ on the map of surface mass-balance rates $\left(\mathrm{D}^{\prime \prime}-\mathrm{D}^{\prime}\right.$ drainage system) drawn by Giovinetto and Bentley (1985).

\subsection{Site selection}

Several authors (Watanabe, 1978; Pettre and others, 1986; Goodwin, 1990) have pointed out the influence of katabatic winds on the net annual accumulation. These winds are the main element acting on the glacier surface that causes high surface ablation rates and snow transport/redistribution and makes the interpretation of chemical, isotopic and physical profiles difficult. Surface air does not blow radially and uniformly away from the highest part of the ice sheet, but rather is highly irregular, with regions of pronounced confluence and divergence. To identify the sites as little disturbed as possible by 
Table 1. Mean accumulation rates, $\delta^{18} \mathrm{O}$ and mean annual temperature for different sites in northern Victoria Land (sites 1-19 are shown in Fig. 1)

\begin{tabular}{|c|c|c|c|c|c|c|c|}
\hline \multirow[t]{2}{*}{ No. } & \multirow[t]{2}{*}{ Site } & \multirow[t]{2}{*}{ Location } & \multirow{2}{*}{$\begin{array}{l}\text { Elevation } \\
\text { ma.s.l. }\end{array}$} & \multirow{2}{*}{$\begin{array}{l}\text { Accumulation } \\
\text { rate } \\
\mathrm{kg} \mathrm{m}^{-2} \mathrm{a}^{-1}\end{array}$} & \multirow{2}{*}{$\begin{array}{c}\delta^{18} O \\
\% \text { V-SMOW }\end{array}$} & \multirow{2}{*}{$\begin{array}{c}\text { Mean annual } \\
\text { temp. } \\
{ }^{\circ} \mathrm{C}\end{array}$} & \multirow[t]{2}{*}{ Source } \\
\hline & & & & & & & \\
\hline 1 & Hallet station & $170^{\circ} 18^{\prime} \mathrm{E}, 72^{\circ} 18^{\prime} \mathrm{S}$ & 5 & $183^{(1)}$ & - & $-15.3^{(7)}$ & Duphorn (1981) \\
\hline 2 & E10 & $164^{\circ} \mathrm{E}, 72^{\circ} 20^{\prime} \mathrm{S}$ & 2305 & $50^{(2)}$ & - & - & Allen and others (1985) \\
\hline 3 & ST559 & $161^{\circ} 32^{\prime} \mathrm{E}, 72^{\circ} 38^{\prime} \mathrm{S}$ & 1720 & $163^{(3)}$ & - & - & Stuart and Heine (1961) \\
\hline 4 & Hercules Névé & $165^{\circ} 28^{\prime} \mathrm{E}, 73^{\circ} 06^{\prime} \mathrm{S}$ & 2960 & $161^{(2)}, 142^{(2),(4)}$ & $-33.62^{(6)}$ & $-33.1^{(8)}$ & Maggi and others (1998) \\
\hline 5 & Hercules Névé & $165^{\circ} 28^{\prime} \mathrm{E}, 73^{\circ} 06^{\prime} \mathrm{S}$ & 2960 & $119^{(2)}, 131^{(5)}$ & $-34.33^{(6)}$ & $-33.1^{(8)}$ & Stenni and others (1999) \\
\hline 6 & Hercules Névé & $164^{\circ} 58^{\prime} \mathrm{E}, 73^{\circ} 07^{\prime} \mathrm{S}$ & 3000 & $145^{(5)}$ & -33.59 & $-34.0^{(9)}$ & This paper \\
\hline 7 & Priestley Névé & $160^{\circ} 09^{\prime} \mathrm{E}, 73^{\circ} 38^{\prime} \mathrm{S}$ & 1980 & $146^{(1)}$ & -36.50 & $-35.1^{(7)}$ & Stenni (1999) \\
\hline 8 & Campbell Glacier C & $163^{\circ} 20^{\prime} \mathrm{E}, 73^{\circ} 45^{\prime} \mathrm{S}$ & 1560 & $150-180$ & -33.53 & $-25.3^{(10)}$ & Gragnani and others (1998) \\
\hline 9 & Aviator Glacier & $165^{\circ} 06^{\prime} \mathrm{E}, 73^{\circ} 51^{\prime} \mathrm{S}$ & 150 & $260^{(4)}$ & -24.78 & $-18.2^{(10)}$ & Caprioli and others (1998) \\
\hline 10 & Styx Glacier & $163^{\circ} 41^{\prime} \mathrm{E}, 73^{\circ} 52^{\prime} \mathrm{S}$ & 1700 & $160^{(4)}$ & - & - & Piccardi and others (1994a, b) \\
\hline 11 & Styx Glacier & $163^{\circ} 45^{\prime} \mathrm{E}, 73^{\circ} 55^{\prime} \mathrm{S}$ & 1800 & $203^{(2)}$ & -32.90 & $-29.0^{(8)}$ & This paper \\
\hline 12 & Campbell Glacier B & $164^{\circ} 04^{\prime} \mathrm{E}, 74^{\circ} 15^{\prime} \mathrm{S}$ & 800 & $150-170$ & -27.25 & $-21.5^{(10)}$ & Gragnani and others (1998) \\
\hline 13 & Mount Melbourne & - & 480 & - & -20.00 & $-20.0^{(10)}$ & Stenni (1999) \\
\hline 14 & Mount Melbourne 2 & - & 700 & 200 & - & $-18.5^{(10)}$ & Lyon (1986) \\
\hline 15 & McCarthy Ridge & $162^{\circ} 56^{\prime} \mathrm{E}, 74^{\circ} 33^{\prime} \mathrm{S}$ & 700 & $270^{(4)}$ & - & - & Piccardi and others (1994a, b) \\
\hline 16 & McCarthy Ridge & $163^{\circ} 03^{\prime} \mathrm{E}, 74^{\circ} 36^{\prime} \mathrm{S}$ & 650 & $260^{(2)}$ & -25.48 & $-20.8^{(10)}$ & This paper \\
\hline 17 & Campbell Glacier A & $164^{\circ} 30^{\prime} \mathrm{E}, 74^{\circ} 41^{\prime} \mathrm{S}$ & 50 & - & -23.92 & $-17.8^{(10)}$ & Gragnani and others (1998) \\
\hline 18 & Strandline Glacier & $164^{\circ} 02^{\prime} \mathrm{E}, 74^{\circ} 42^{\prime} \mathrm{S}$ & 82 & - & - & $-14.3^{(8)}$ & Rossi (1991) \\
\hline 19 & Drygalski Ice Tongue & $165^{\circ} 19^{\prime} \mathrm{E}, 75^{\circ} 31^{\prime} \mathrm{S}$ & 40 & $160^{(2)}$ & -22.20 & $-20.0^{(8)}$ & Caprioli and others (1998) \\
\hline 20 & Litell Rocks & $162^{\circ} 20^{\prime} \mathrm{E}, 71^{\circ} 00^{\prime} \mathrm{S}$ & 680 & - & - & $-16.5^{(8)}$ & Allen and others (1985) \\
\hline 21 & $\mathrm{Ml}$ & $162^{\circ} 00^{\prime} \mathrm{E}, 71^{\circ} 40^{\prime} \mathrm{S}$ & 1400 & $182^{(2)}$ & - & - & Allen and others (1985) \\
\hline 22 & McMurdo & $166^{\circ} 44^{\prime} \mathrm{E}, 77^{\circ} 51^{\prime} \mathrm{S}$ & 24 & $188^{(1)}$ & - & $-17.4^{(7)}$ & Mullan and Sinclair (1990) \\
\hline
\end{tabular}

${ }^{(1)}$ Stake measurement. ${ }^{(2)}$ Chemical analysis of snow/firn core. ${ }^{(3)}$ Snow-pit stratigraphy. ${ }^{(4)}$ Chemical analysis of snow pit. ${ }^{(5)}$ Average $1965-93 .{ }^{(6)}$ Mean $\delta^{18} \mathrm{O}$ for the upper $8 \mathrm{~m}$. ${ }^{(7)}$ Meteorological station. ${ }^{(8)} 10 \mathrm{~m}$ depth temperature. ${ }^{(9)} 7 \mathrm{~m}$ depth temperature. ${ }^{(10)} T\left({ }^{\circ} \mathrm{C}\right)=0.005(\mathrm{Hm})-17.5$.

the action of katabatic winds, a study of the surface wind field of the the Terra Nova Bay area (about $100000 \mathrm{~km}^{2}$ ) was carried out (Frezzotti, 1998). Remote sensing can provide information about the surface wind field through the location, direction and aerial extension of epiglacial aeolian morphology and ablation-area survey. The survey was carried out using aerial photographs and satellite images at scales between 1:50000 and 1:100000. Field investigation on sastrugi, snowdrifts and other aeolian morphologies was performed in order to check the remote-sensing survey. A final map was drawn at 1:500 000 scale (Frezzotti, 1998). Comparison between different documents, taken several years apart, and field surveys shows the time persistence of the shape and size of the aeolian morphologies, at the analysis scale. These analyses of the surface wind field of Terra Nova Bay indicated that McCarthy Ridge $\left(163^{\circ} 01^{\prime} \mathrm{E}, 74^{\circ} 33^{\prime} \mathrm{S}\right)$, Styx Glacier $\left(163^{\circ} 45^{\prime} \mathrm{E}, 73^{\circ} 55^{\prime} \mathrm{S}\right)$ and Hercules Névé $\left(164^{\circ} 58^{\prime} \mathrm{E}, 73^{\circ} 07^{\prime} \mathrm{S}\right)$ were least influenced by the katabatic winds (Fig. 1).

McCarthy Ridge is a plateau area of approximately 100 $\mathrm{km}^{2}$, located at about $700 \mathrm{~m}$ a.s.l. between the Eisenhower Range to the east and the Nansen Ice Sheet to the west, with the Priestley Glacier valley to the north and the Reeves Glacier valley to the south. This sampling site is in the path of the katabatic winds that flow down along the Priestley and Reeves valleys but is protected from these winds by the Eisenhower Range. The site is $40 \mathrm{~km}$ from the permanent polynya of the Terra Nova Bay.

Styx Glacier plateau, approximately $150 \mathrm{~km}^{2}$ in area, is located between the Campbell and Tinker Glacier valleys, about $50 \mathrm{~km}$ from the sea (Wood Bay) and at about $1700 \mathrm{~m}$ a.s.l. The analyses of the wind field showed that the katabatic winds coming from the west and southwest pass over the Deep Freeze Range and affect the leeward area of this chain as seen from the Campbell Glacier right hydrographic. On the eastern part of the Campbell Glacier valley, where the Styx Glacier plateau lies, the wind effect is strongly reduced, causing some snowdrifts in the west-east direction.

Hercules Névé is a plateau of approximately $1100 \mathrm{~km}^{2}$, at about $3000 \mathrm{~m}$ a.s.l., and about $75 \mathrm{~km}$ from the sea (Lady Newnes Bay); together with the adjacent Evans Névé, it makes up the largest ice cap of northern Victoria Land. The sampling site is located on the ice divide between the glaciers that flow into the Ross Sea and those that flow into the Pacific Ocean. The distribution of the wind morphology exhibits a radial distribution, showing that the area is not affected by katabatic winds. Temperature values of $-34.5^{\circ}$ and $-33.1^{\circ} \mathrm{C}$ at 7.5 and $10 \mathrm{~m}$ depth, respectively, were measured in a borehole.

\section{EXPERIMENTAL}

\subsection{Sampling}

Three firn cores were drilled during the Italian Antarctic Campaigns 1991/92 and 1992/93 at McCarthy Ridge, Styx Glacier and Hercules Névé stations (core lengths 6.5, 9 and $7.5 \mathrm{~m}$, respectively).

The firn-core sections (about $50 \mathrm{~cm}$ long; $d=10 \mathrm{~cm}$ ) were kept frozen and brought to the cold laboratory of the University of Milan. After decontamination by removing a thin external layer, subsamples were obtained by cutting the firn cores every $3 \mathrm{~cm}$ (Hercules Névé) and $5 \mathrm{~cm}$ (McCarthy Ridge and Styx Glacier). Chemical, stratigraphic and stable-isotope analyses were carried out on these samples.

\subsection{Firn-core analysis}

Before samples were taken for the chemical and isotopic analyses, the firn cores were studied to provide a detailed logging of the internal characteristics of the firn. The size 
and shape of the crystals and pores and the presence and thickness of each ice crust were measured to obtain a continuous stratigraphy of these characteristics.

\subsubsection{Isotopic composition}

The measurement of oxygen isotopic composition was carried out according to the Epstein and Mayeda (1953) technique of isotopic equilibration of $\mathrm{CO}_{2}$ with water. The McCarthy and Styx samples were prepared manually and measured by a Finnigan Delta $\mathrm{S}$ mass spectrometer for their ${ }^{18} \mathrm{O} /{ }^{16} \mathrm{O}$ ratios, while the Hercules Névé samples were prepared using an automatic equilibration device (Isoprep 18) in line with an Optima VG mass spectrometer.

The results are reported as $\delta$ units per mil vs Vienna standard mean ocean water ( $\mathrm{V}$-SMOW) isotopic standard (Gonfiantini, 1978).

The mean standard deviation of oxygen measurements was \pm 0.07 per mil $(1 \sigma)$ for the manual preparations and \pm 0.10 per mil for the automatic preparation device.

\subsubsection{Chemical analysis}

The determination of $\mathrm{H}_{2} \mathrm{O}_{2}$ was carried out using a flow analysis method with a spectrofluorimetric detector. This method is based on the formation of a fluorescent dimer from the reaction of p-hydroxyphenylacetic acid with $\mathrm{H}_{2} \mathrm{O}_{2}$ in the presence of peroxidase (Hwang and Dasgupta, 1985). The measurements were performed with an RF-551 Shimadzu spectrofluorimetric detector connected to a peristaltic system.

The determinations of MSA and of the ionic species necessary to calculate $\mathrm{nssSO}_{4}{ }^{2-}$ (total $\mathrm{SO}_{4}{ }^{2-}, \mathrm{Cl}^{-}$) were carried out by ion chromatography (IC) using a Dionex IC 4000i apparatus, Dionex AS4A and AS1l anion separator columns and a conductometric detector with a membrane conductivity suppressor.

The analytical determinations and method performances for these substances are discussed in detail in Piccardi and others (1994a), Udisti and others (1994) and Udisti (1996).

\section{RESULTS AND DISGUSSION}

\subsection{Stratigraphy}

\subsubsection{McCarthy Ridge}

The firn core has a fairly undifferentiated stratigraphy (Fig. 2a) with a very weak variation in the pore size. According to Kuhn (1970), these crystals are characteristic of normal snowfalls with formation temperatures below $-20^{\circ} \mathrm{C}$. No ice crusts were observed along the core.

\subsubsection{Styx Glacier}

In the upper part, from the surface to $4.2 \mathrm{~m}$ depth (Fig. 2b), there is a large, irregular porosity with an average pore dimension of $2-3 \mathrm{~mm}$. Inside this area there are levels composed of denser facies (average porosity $1 \mathrm{~mm}$ ) with thickness ranging from a few $\mathrm{cm}$ (probably due to the very cold snowfall) to $20 \mathrm{~cm}$ (probably indicative of an entire season).

The intermediate part, at $4.20-8.30 \mathrm{~m}$ depth, is less porous, with an average pore size of about $1 \mathrm{~mm}$ and more regular pores. This area is much more homogeneous than the upper area and presents less dense levels (maximum thickness $5 \mathrm{~cm}$, porosity $2-3 \mathrm{~mm}$ ).

The lower part, from $8.20 \mathrm{~m}$ depth to the bottom of the hole, has a pore size of $<1 \mathrm{~mm}$. Ice crusts $0.5-2 \mathrm{~mm}$ thick were observed.

\subsubsection{Hercules Névé}

Here, the transition from the less dense to the denser facies occurs at $3 \mathrm{~m}$ depth, in a gradual but faster way (Fig. 2c). Ice crusts are present here too, especially in the superficial part, with a thickness of $1-2 \mathrm{~mm}$. These are also summer crusts, but are probably due to vapour condensation formed in sunny periods since strong katabatic winds are not present here. In this station as well, the ice crusts cannot be used for annual dating.
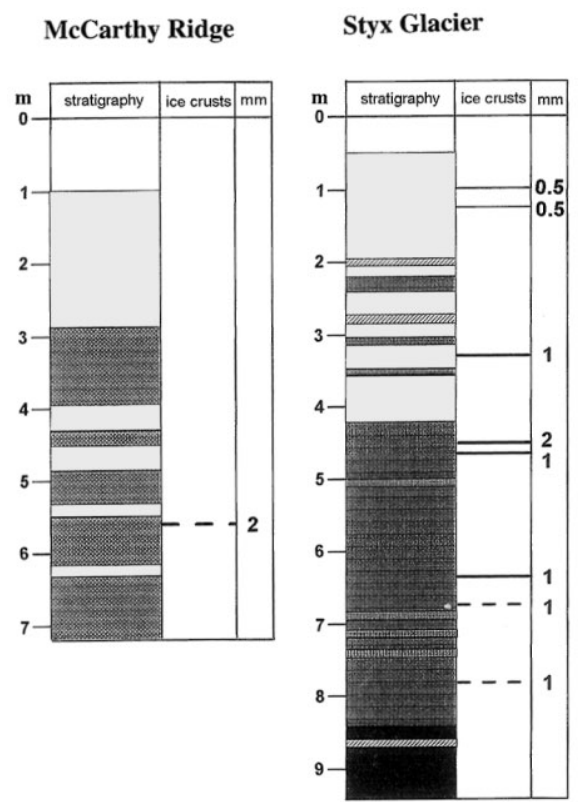

\section{Hercules Névé}

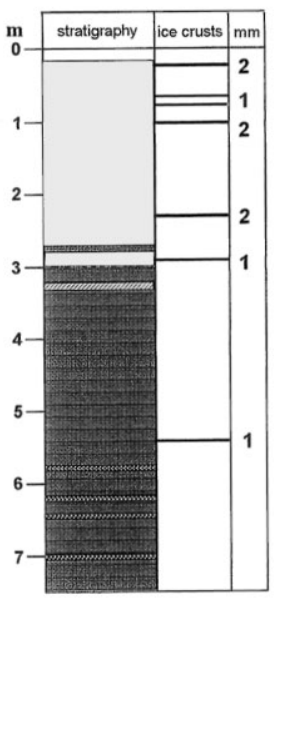

\section{Legend}

Styx Glacier and Hercules Névé
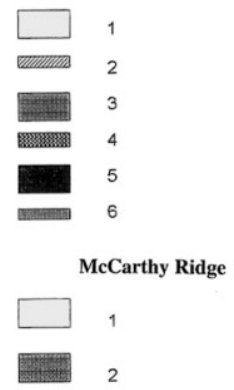

Fig. 2. Stratigraphic profiles of the firn cores drilled at McCarthy Ridge, Styx Glacier and Hercules Névé stations. The first column shows a simplified stratigraphy, the second column shows the ice crusts and the third their thickness. McCarthy Ridge: 1. Crystal size 0.2-0.5 mm; pore diameter 2-5 mm. 2. Crystal size 0.2-0.5 mm; pore diameter 1-3 mm. Styx Glacier and Hercules Névé: 1. Crystal size 0.3-0.6 mm; pore diameter 1-3 mm. 2. The same, but layer thickness < $5 \mathrm{~cm}$. 3. Crystal size 0.3-0.6 mm; pore diameter $1 \mathrm{~mm}$. 4. The same, but layer thickness $<5 \mathrm{~cm}$. 5. Crystal size $0.3-0.6 \mathrm{~mm}$; pore diameter $<1 \mathrm{~mm}$. 6. Crystal size $0.3-0.6 \mathrm{~mm}$; pore diameter $1-3 \mathrm{~mm}$; layer thickness $<5 \mathrm{~cm}$. 


\subsection{Dating and accumulation rate by $\delta^{18} \mathrm{O}$ and chemical profiles}

Table 2 reports the basic statistical parameters for $\mathrm{nssSO}_{4}{ }^{2-}$, MSA, $\mathrm{H}_{2} \mathrm{O}_{2}$ and $\delta^{18} \mathrm{O}$ values measured at the three stations.

The nss $\mathrm{SO}_{4}{ }^{2-}$ concentration refers to the contribution of sulphate not coming from sea spray and is calculated using the following formula:

$$
\left[\mathrm{nssSO}_{4}{ }^{2-}\right]=\left[\mathrm{SO}_{4}{ }^{2-}\right]_{\text {tot }}-0.139 *\left[\mathrm{Cl}^{-}\right],
$$

where $\left[\mathrm{SO}_{4}{ }^{2-}\right]$ and $[\mathrm{Cl}]$ are the concentrations measured in the sample and 0.139 is their concentration ratio $(\mathrm{w} / \mathrm{w})$ in sea water. As only inorganic anions were determined by IC in all the firn-core samples (sample volume was often insufficient for cation analysis), we used $\mathrm{Cl}^{-}$concentration as the sea-spray marker. Actually, in northern Victoria Land the more reliable sea-spray marker is $\mathrm{Na}^{+}$because $\mathrm{Cl}^{-}$may come from other sources (e.g. volcanic $\mathrm{HCl}$ ) or may undergo fractionating effects able to change the original sea-spray composition during transport (Piccardi and others, 1996a; Udisti and others, 1998b). Nevertheless, previous $\mathrm{nssSO}_{4}{ }^{2}$ measurements on snow-pit samples collected at the same stations indicated that the use of $\mathrm{Cl}^{-}$or $\mathrm{Na}^{+}$as a sea-spray marker gives very similar nss $\mathrm{SO}_{4}{ }^{2-}$ values when the $\mathrm{nssSO}_{4}{ }^{2-}$ concentration levels are not too low (Piccardi, 1994a; Udisti, 1996). A satisfactory correlation $(R=0.97$, slope $=0.91)$ was obtained between $\mathrm{nssSO}_{4}{ }^{2-}$ values calculated by sodium concentration and by chloride concentration, for 184 of the Hercules Névé samples for which the volume was sufficient to determine the $\mathrm{Na}^{+}$content. Similar results were obtained by Ayers and others (1991) in aerosol measurements.

Negative $\mathrm{nssSO}_{4}{ }^{2-}$ values were sometimes found in the samples. These were usually found in snow and ice samples with high sea-spray content, collected in winter (low biogenic activity) at low-altitude coastal stations (Maupetit and Delmas, 1992; Piccardi and others, 1994a, 1996a, b; Udisti, 1996; Wagenbach, 1996).

Figure 3 shows the smoothed (order 5) $\mathrm{nssSO}_{4}{ }^{2-}$ and original $\mathrm{Cl}^{-}$profiles at the three stations. The "background" chloride values decrease with increasing altitude, showing the highest mean value at McCarthy station $\left(1570 \pm 1037 \mu \mathrm{g} \mathrm{L}^{-1}\right)$ and the lowest at Hercules Névé $\left(279 \pm 366 \mu \mathrm{g} \mathrm{L}^{-1}\right)$. The depth/concentration profiles are modulated by sudden spikes, occurring mainly in the winter period and probably due to salt storms. Comparison between the $\mathrm{nssSO}_{4}{ }^{2-}$ and $\mathrm{Cl}^{-}$profiles shows that the nssSO $_{4}{ }^{2-}$ negative values, especially evident for the lowest station, are generally coincident with the $\mathrm{Cl}^{-}$winter peaks.

The negative values may result from an incorrect interpretation of the $\mathrm{SO}_{4}{ }^{2-} / \mathrm{Cl}^{-}$or $\mathrm{Na}^{+}$ratio in sea water, from analytical errors in anion determination or from fractionating effects of the sea-spray components during the transport of the marine aerosol (Keene and others, 1986; Hawley and others, 1988; Piccardi and others, 1996a; Wagenbach and others, 1998). An unequivocal opinion about the correction of the $\mathrm{nssSO}_{4}{ }^{2-}$ calculation to avoid negative values is lacking, so in Table 2 we report the statistical parameters related both to all the values (positive and negative) and to the positive ones only.

\subsubsection{Dating}

For dating purposes, we applied the multiparametric method for chemical dating proposed by Udisti (1996). An essential abstract of the method is reported here.

The chemical concentration/depth profiles (Figs $4 \mathrm{a}-\mathrm{c}$, $5 \mathrm{a}-\mathrm{c}$ and $6 \mathrm{a}-\mathrm{c}$ ) were normalized by dividing each analytical value by the maximum value found in the same temporal series in the interval of amplitude $2 q+1$ (the chosen value, $q$ data before and $q$ data after) around the considered analytical value. $q$ is an arbitrary value that permits better identification of summer peaks even when a low summer peak for a year is near to very high summer peaks belonging to adjacent years. The ideal aim of the normalization procedure is to attribute a value of 1 to summer peaks, independently of their analytical value. For all the firn cores considered, an interval value of 21 was chosen $(q=10)$. The smoothed sum (Figs 4d, 5d and 6d) of the three normalized profiles gives a new depth profile with maximum values of 3 for depths at which all the parameters show a summer peak (normalized height $=1$ ), and minimum values when the temporal series do not present high concentration values.

For dating purposes, the negative $\mathrm{nssSO}_{4}{ }^{2-}$ values are not a problem, because the normalized sum is built to spot the summer maxima, while the negative values are mainly found in the winter period.

For each firn core, the definitive dating decision comes from visual comparison of the relative normalized sum (chemical seasonal marker) and the isotopic profile.

The possible temporal dephasing between the different parameters used for chemical and isotopic profiles can sometimes result in a small shift between the relative summer maxima. However, the agreement between the two temporal series is generally good.

\subsubsection{McCarthy Ridge}

Figure 4 shows the depth profiles of the analytical parameters used for the McCarthy Ridge firn-core dating. Figure $4 \mathrm{a}-\mathrm{c}$ show the concentration/depth profiles of $\mathrm{H}_{2} \mathrm{O}_{2}, \mathrm{nssSO}_{4}{ }^{2-}$ and MSA, respectively. A sharp seasonal behaviour is evident for

Table 2. Fundamental statistical parameters for the components used for dating at the three sampling stations

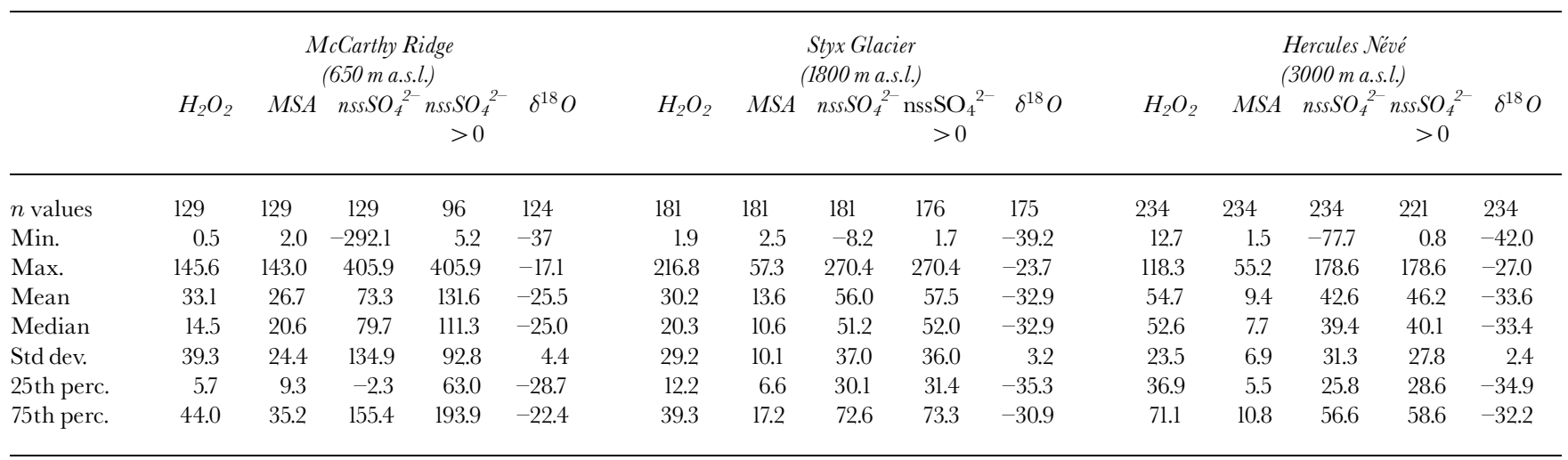



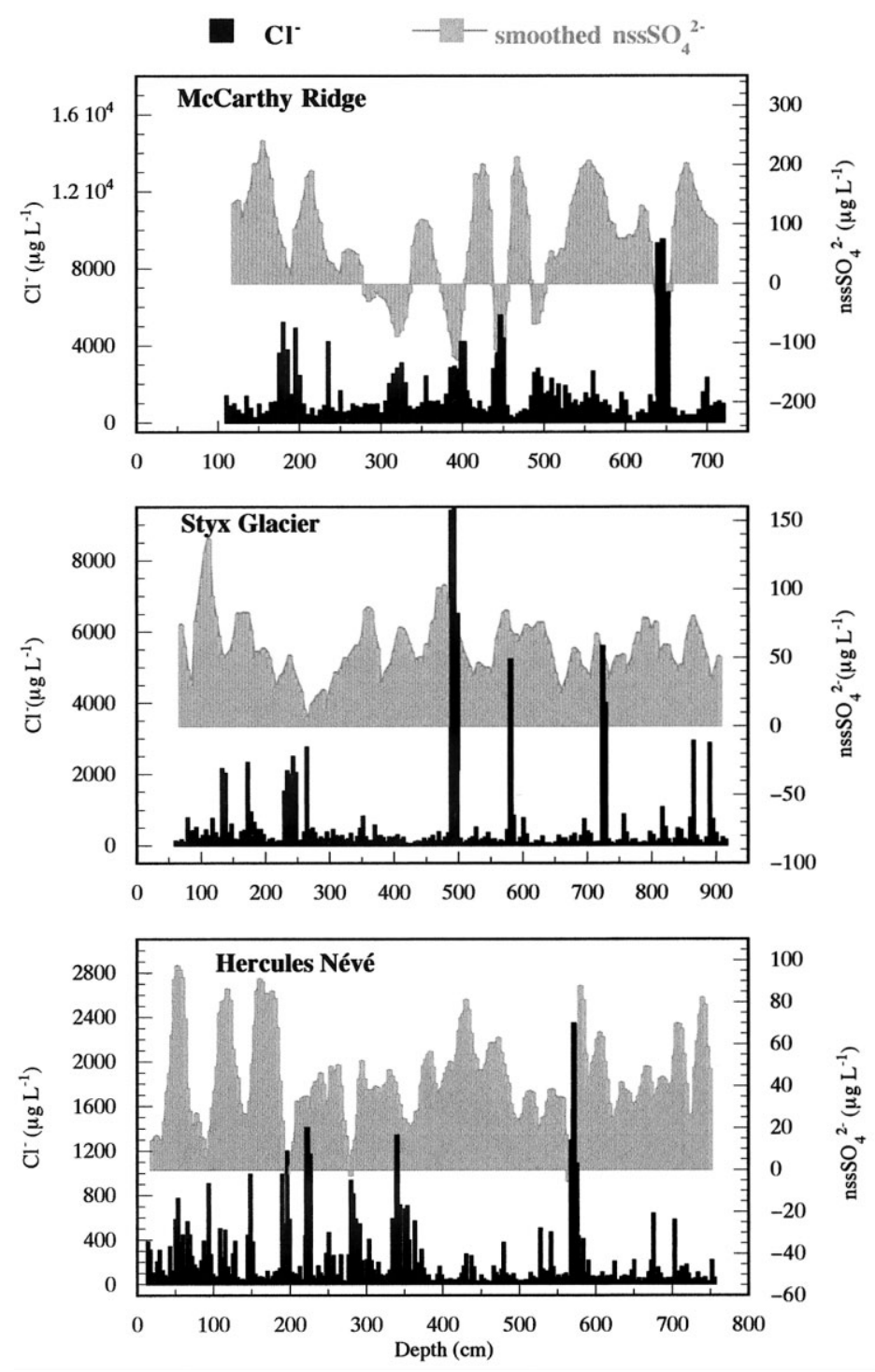

Fig. 3. Concentration/depth profiles for the three ice cores of nss $\mathrm{SO}_{4}{ }^{2-}$ (order 3 smoothed) and $\mathrm{Cl}$.

all the concentration profiles, with summer peaks relatively low in some years and very high in others. For example, the $\mathrm{H}_{2} \mathrm{O}_{2}$ profile shows a summer concentration maximum of $70 \mu \mathrm{g} \mathrm{L}^{-1}$ at around $220 \mathrm{~cm}$ depth and of $150 \mu \mathrm{g} \mathrm{L}^{-1}$ at $600 \mathrm{~cm}$ depth. This summer peak is also very broad $(550-650 \mathrm{~cm})$, which could indicate a large summer snow accumulation for that year or a very low winter snow accumulation for two or more successive years (see below).

The $\mathrm{nsSSO}_{4}{ }^{2-}$ profile (Fig. 4b) includes quite a large number of negative values (about 25\%) and shows more homogeneous summer peaks. By contrast, the MSA concentration profile (Fig. 4c) shows higher values for the first 2 years, with a maximum value of $143 \mu \mathrm{g} \mathrm{L}^{-1}$ at $210 \mathrm{~cm}$ depth.

The observed variations of the $\delta^{18} \mathrm{O}$ values obtained along the profile (Fig. 4e) are related to seasonal temperature variations. The $\delta^{18} \mathrm{O}$ seasonal trend seems to be quite regular, except for two small intervals at depths of 300-450 and $580-670 \mathrm{~cm}$. At about $240 \mathrm{~cm}$, a large negative $\delta^{18} \mathrm{O}$ value suggests a low precipitation temperature.

For this station, the best seasonal tracer seems to be $\mathrm{H}_{2} \mathrm{O}_{2}$. However, a comparative examination of all three concentration profiles can give a more reliable summer peak identification. Figure $4 \mathrm{~d}$ shows the relative normalized smoothed (order 3) sum. In the normalized sum, it is possible to recognize nine well-defined summer peaks, indicated by the numbers $1-5,6-8$ and 10 , and two small peaks $\left(5^{\prime}\right.$ and $\left.8^{\prime}\right)$. Peak 9 will be discussed later. The main problem with the dating interpretation is the large peak at $550-650 \mathrm{~cm}$ depth that could either be single or include three summer peaks $\left(8,8^{\prime}\right.$ and 9$)$.

The weak changes in firn facies evidenced by visual stratigraphy are not relevant for dating purposes. It is only possible to observe, close to the bottom section, a fairly good correlation between summer peaks 8-10 and the denser firn facies. However, the $2 \mathrm{~mm}$ ice crusts at $560 \mathrm{~cm}$ depth correspond to $\mathrm{H}_{2} \mathrm{O}_{2}$ peak 8 , the widest peak of all the stratigraphy.

The chemical profile may be compared to the $\delta^{18} \mathrm{O}$ profile (Fig. 4e). Peaks $1-5,6-8$ and 10 are fully confirmed. The peak indicated as $5^{\prime}$ is not visible in the $\delta^{18} \mathrm{O}$ profile and is discarded. The same is true for peak $8^{\prime}$, which is very small in the two series. The isotopic profile contains, instead, peak 9, which is visible with difficulty in the normalized sum. We consider this as a summer peak, because of its welldefined shape in the isotopic profile. In the end, we found $10 \pm 1$ summer peaks. An uncertainty of $10 \%$ is acceptable for estimating a reliable mean snow-accumulation rate. The ten peaks identify nine accumulation years in the depth range $160-680 \mathrm{~cm}$, so an accumulation rate of $57.8 \mathrm{~cm}$ snow a ${ }^{-1} \mathrm{can}$ be calculated. By considering the annual mean density of each year (calculated on about 30 firn-core sections), a mean accumulation rate of $260 \mathrm{~kg} \mathrm{~m}^{-2} \mathrm{a}^{-1}$ is estimated. This result is in full agreement with the value of $270 \mathrm{~kg} \mathrm{~m}^{-2} \mathrm{a}^{-1}$ found for 

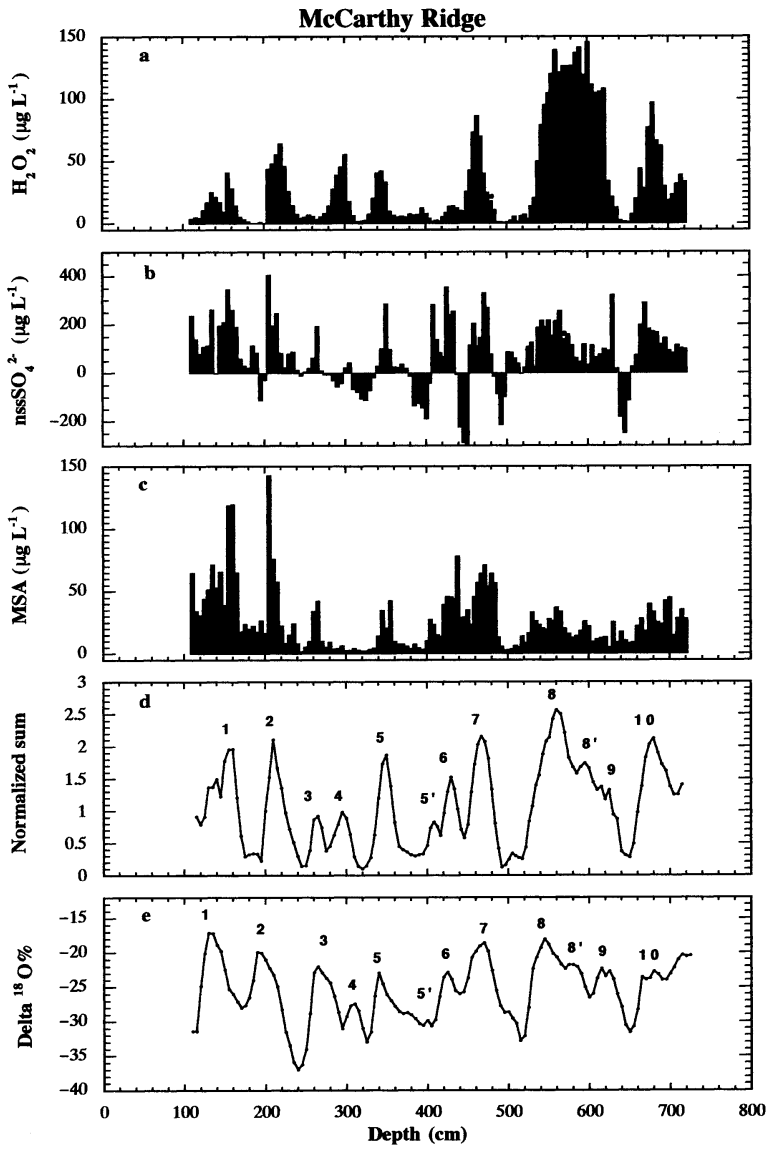

Fig. 4. McCarthy Ridge station: depth profiles of $\mathrm{H}_{2} \mathrm{O}_{2}(a)$, nsS $\mathrm{SO}_{4}^{2-}(b), \mathrm{MSA}(\mathrm{c})$, normalized sum (d) and $\delta^{18} \mathrm{O}(\mathrm{e})$. For calculation of normalized sum profile from original $\mathrm{H}_{2} \mathrm{O}_{2}$, nsS $\mathrm{SO}_{4}{ }^{2-}$ and MSA concentration values see text.

a $2 \mathrm{~m}$ deep snow pit excavated at the same station in the Italian Antarctic Campaign 1990/91 (Piccardi and others, 1994a). Referring to the mean accumulation rate, the first peak may be ascribed to summer 1988/89 and the last peak to summer 1979/80.

\subsubsection{Styx Glacier}

The concentration/depth profiles for the Styx Glacier station of $\mathrm{H}_{2} \mathrm{O}_{2}, \mathrm{nssSO}_{4}{ }^{2-}$ and $\mathrm{MSA}$ are shown in Figure $5 \mathrm{a}-\mathrm{c}$, respectively. Here too, a clear seasonal behaviour, with summer maxima and winter minima, can be observed for all the components. The highest $\mathrm{H}_{2} \mathrm{O}_{2}$ summer peaks are located at the surface (about $220 \mu \mathrm{g} \mathrm{L}^{-1}$ ) and at $440 \mathrm{~cm}$ (about $110 \mu \mathrm{g} \mathrm{L}^{-1}$ ). The $\mathrm{nssSO}_{4}{ }^{2-}$ concentration/depth profile (Fig. $5 \mathrm{~b})$ shows very few negative values $(2.3 \%$, as opposed to $25 \%$ at McCarthy Ridge). For this station, higher than McCarthy Ridge, the sea-spray contribution is much lower (Fig. 3) and the contribution of secondary marine aerosol $\left(\mathrm{nsSSO}_{4}{ }^{2-}\right.$ and MSA) becomes relatively more important. The highest $\mathrm{nsSSO}_{4}{ }^{2-}$ concentration was measured at the second summer peak (about $270 \mu \mathrm{g} \mathrm{L}^{-1}$ ), and corresponds to the highest concentration for the MSA profile (Fig. 5c; about $58 \mu \mathrm{g} \mathrm{L}^{-1}$ ).

The seasonal variations of $\delta^{18} \mathrm{O}$ observed along the firn core recovered at Styx Glacier (Fig. 5e) show a regular pattern, with a slight negative trend of the mean value in the first $350 \mathrm{~cm}$ followed by an extremely high and wide peak (at about $425 \mathrm{~cm}$ ) probably corresponding to relatively high depositional temperatures. This peak is almost coincident with the large $\mathrm{H}_{2} \mathrm{O}_{2}$ peak mentioned above.

The normalized sum profile is plotted in Figure $5 \mathrm{~d}$. By comparing the normalized sum and the $\delta^{18} \mathrm{O}$ profiles, 18
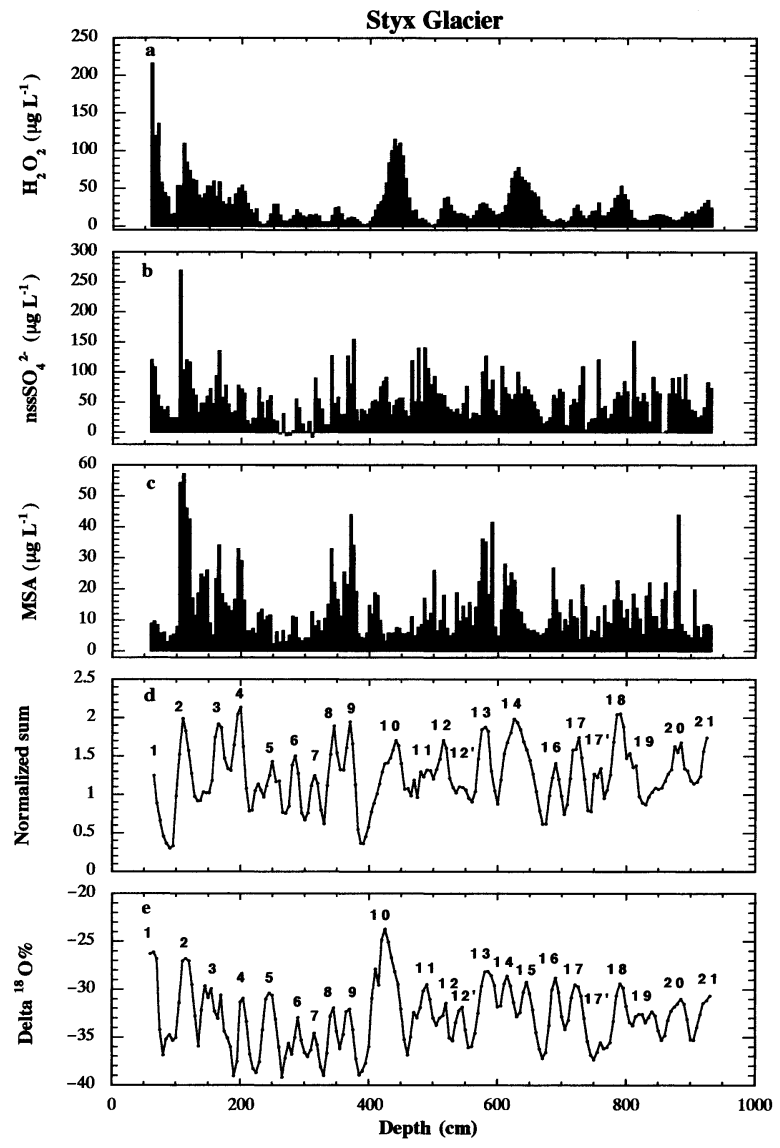

Fig. 5. Styx Glacier station: depth profiles of $\mathrm{H}_{2} \mathrm{O}_{2}(a)$, nss $\mathrm{SO}_{4}{ }^{2-}(b), \mathrm{MSA}(c)$, normalized sum (d) and $\delta^{18} \mathrm{O}$ (e). For calculation of normalized sum profile from original $\mathrm{H}_{2} \mathrm{O}_{2}, \mathrm{nsSSO}_{4}{ }^{2-}$ and MSA concentration values see text.

sharp summer peaks (Nos 1-10, 12, 13-14, 16-21) can be observed. Peaks $8-10$ have different heights but exactly the same shape in the chemical and isotopic profiles. Peaks 11, $12^{\prime}, 15$ and 19 are absent or very low in the normalized sum profile but well defined in the $\delta^{18} \mathrm{O}$ profile; by contrast, peak $17^{\prime}$ is evident in the chemical profile but not in the $\delta^{18} \mathrm{O}$ profile. By considering peaks $11,17^{\prime}$ and 19 as more reliable, it is possible to identify $21 \pm 2$ summer peaks (uncertainty of $10 \%$ ), corresponding to 20 years of accumulation in the depth range $65-925 \mathrm{~cm}$. A mean snow accumulation rate of $43.0 \mathrm{~cm} \mathrm{a}^{-1}$ can be calculated. By considering the annual mean density for each year (calculated on about 36 firn-core sections), a mean snow-accumulation rate of $203 \mathrm{~kg} \mathrm{~m}^{-2} \mathrm{a}^{-1}$ is estimated. Using this mean accumulation rate, the first peak can be related to summer 1990/91, and the last peak to summer 1970/71.

The value of $203 \mathrm{~kg} \mathrm{~m}^{-2} \mathrm{a}^{-1}$ is considerably higher than that of $160 \mathrm{~kg} \mathrm{~m}^{-2} \mathrm{a}^{-1}$ calculated for a $2 \mathrm{~m}$ deep snow pit excavated during the 1990/91 Italian expedition at the same station (Piccardi and others, 1994b; Udisti, 1996). The higher accumulation rate can be explained by very high snow accumulation for some years: 1982 (peaks 9-10: $320 \mathrm{~kg} \mathrm{~m}^{-2} \mathrm{a}^{-1}$ ), 1979 (peaks 12-13: $316 \mathrm{~kg} \mathrm{~m}^{-2} \mathrm{a}^{-1}$ ) and 1977 (peaks 14-16: $\left.334 \mathrm{~kg} \mathrm{~m}^{-2} \mathrm{a}^{-1}\right)$. The last two of these high-accumulation periods include the most uncertain dating (the disregarded $12^{\prime}$ and 15 peaks). If just one of these is an annual peak, we obtain a mean annual accumulation rate of $184 \mathrm{~kg} \mathrm{~m}^{-2} \mathrm{a}^{-1}$, which is close to the previously reported one.

Visual stratigraphy cannot be used as a tool for dating purposes. However, the comparison with chemical and stable-isotope records permits a correlation of the thin 

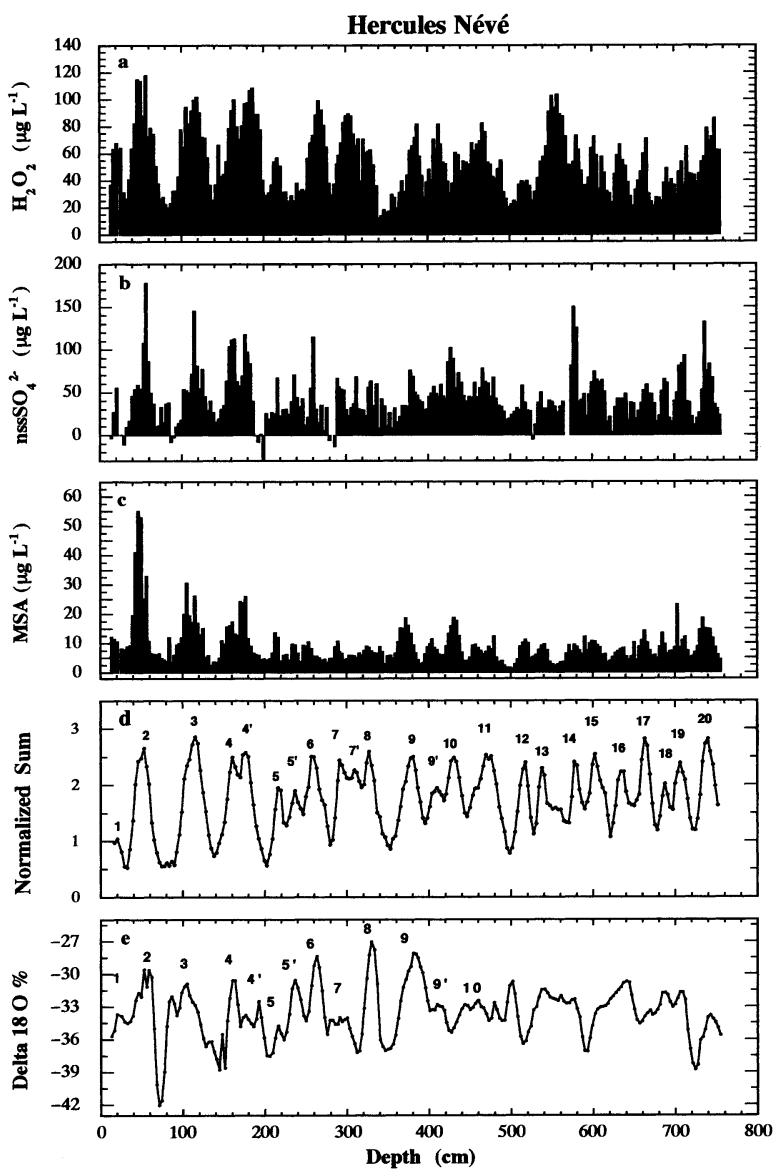

Fig. 6. Hercules Névé station: depth profiles of $\mathrm{H}_{2} \mathrm{O}_{2}(\mathrm{a})$, $n s S_{4}{ }_{4}^{2-}(b), M S A(c)$, normalized sum (d) and $\delta^{18} \mathrm{O}$ (e). For calculation of normalized sum profile from original $\mathrm{H}_{2} \mathrm{O}_{2}, \mathrm{nsSO}_{4}{ }^{2-}$ and MSA concentration values see text.

layers of facies 1 and 2 with summer peaks. The denser layers at depths of 2, 2.7, 6.8 and 7.15 m correspond to peaks 4, 6, 16 and 17, respectively. The other layers and the ice crusts are not related with summer peaks.

\subsubsection{Hercules Névé}

At this station, located at 3000 ma.s.l., the mean $\mathrm{H}_{2} \mathrm{O}_{2}$ concentration value is slightly higher than the mean values calculated for the two lower stations (Table 2), and the $\mathrm{H}_{2} \mathrm{O}_{2}$ depth profile (Fig. 6a) shows relatively high values even in winter. Anyway, the seasonal pattern is clear in the whole firn core except for the three oldest years. By contrast, this depth range (from $650 \mathrm{~cm}$ to the bottom) is well resolved by the temporal trends of the other two parameters, particularly $\mathrm{nssSO}_{4}{ }^{2-}$, which have unclear profiles at other depths (e.g. at 200 and $350 \mathrm{~cm}$ depth; Fig. 6b).

The sea-spray contribution at this station is very low (Fig. 3), and the secondary marine aerosol is dominant with respect to the sea-spray contribution, at least during summer (Piccardi and others, 1996a). As a result, the mean nssSO $_{4}{ }^{2-}$ concentration is $>60 \%$ of the total sulphate, and only a few negative values (about 5\%) were observed, all during the winter periods.

The MSA concentration profile (Fig. 6c) shows a sharp decrease of the summer peaks in the first 3 years. The summer maxima decrease from about $55 \mu \mathrm{g} \mathrm{L}{ }^{-1}$ for the first year to around $10-20 \mu \mathrm{g} \mathrm{L}^{-1}$ in the depth range $200-760 \mathrm{~cm}$. The MSAvalues are lower than those measured at the lower stations, and for some samples they are only 10 times higher than the detection limit $\left(0.2 \mu \mathrm{g} \mathrm{L}^{-1}\right)$. Notwithstanding this, the seasonal pattern of both the original and normalized profiles is well defined, and this parameter has an important role in dating, even at this high station. The MSA determination is a direct analytical measurement and is not subject to incorrect interpretation, unlike $\mathrm{nssSO}_{4}{ }^{2-}$ determination.

The $\delta^{18} \mathrm{O}$ record obtained at Hercules Névé (Fig. 6e) shows strong seasonal variations in the uppermost $4 \mathrm{~m}$ of the firn core (up to a value of 9-10\%), followed by a smoother trend in the part below, suggesting the presence of homogenization effects, probably caused by water-vapour diffusion in the porous firn. The scarce precipitation at this high-altitude site may explain the partial obliteration of the seasonal isotopic signal. The chemical species are not affected by this phenomenon. Therefore, a comparison of isotopic and chemical profiles is possible only for about the first half of the firn core.

By assuming the chemical profile (normalized sum; Fig. $6 \mathrm{~d}$ ) as a discussion base, 20 well-defined summer peaks (Nos 1-20, Fig. 6d) and 4 not completely resolved, probable summer peaks (peaks $4^{\prime}, 5^{\prime}, 7^{\prime}$ and $9^{\prime}$ ) can be distinguished. Fortunately, all the ambiguous peaks are located in the first part of the firn core, so it is possible to confirm their correspondence with summer peaks using the isotopic profile. By comparing Figure $6 \mathrm{~d}$ and e, we can observe that peak $9^{\prime}$ has the same shape and relative height in the chemical and isotopic profiles. Peak $7^{\prime}$ is missing in the isotopic profile. The $4-4^{\prime}$ and $5-5^{\prime}$ pairs are apparent in both profiles, even if the relative heights are reversed. We assumed peak $9^{\prime}$ to be a summer peak and we discarded the $7^{\prime}$ peak. The $4^{\prime}$ and $5^{\prime}$ peaks remain ambiguous.

In this firn core, the homogeneity of the firn facies does not allow one to follow the seasonality at all. Although a few ice crusts could be related to certain peaks ( 1 and $3 \mathrm{~m}$ depth), the whole stratigraphy does not seem to be related to the chemical and stable-isotope records.

In conclusion, we can identify $22 \pm 2$ summer peaks (uncertainty of $10 \%$ ). The resulting 21 annual snow layers correspond to the $20-740 \mathrm{~cm}$ depth range, leading to a mean snow-accumulation rate of $34.3 \mathrm{~cm} \mathrm{a}^{-1}$. From the mean annual density values (measured every $5 \mathrm{~cm}$ on the entire firn core) we obtained a mean accumulation rate of $159 \mathrm{~kg} \mathrm{~m}^{-2} \mathrm{a}^{-1}$ in the period 1972-92. This mean accumulation value is in good agreement with those reported by Maggi and others (1998) and Stenni and others (1999) for the same station, and by Allen and others (1985) for a nearby area $\left(182 \mathrm{~kg} \mathrm{~m}^{-2} \mathrm{a}^{-1}\right.$; core M1, Rennick Glacier area).

\subsection{Effects of altitude and seasonality on chemical composition}

Figure 7 shows the altitude effect and the seasonal pattern of $\mathrm{Cl}^{-}$, tot $\mathrm{SO}_{4}{ }^{2-}, \mathrm{nssSO}_{4}{ }^{2-}, \mathrm{MSA}$ and $\mathrm{H}_{2} \mathrm{O}_{2}$ for the three firn cores. Each plot reports the mean concentrations (calculated on total, winter and summer samples) as a function of the station altitude. The summer and winter samples were selected on the basis of the sum normalized profiles. Each sample was considered to be a "summer sample" when its normalized sum value was higher than one-half of the maximum peak value, and a "winter sample" otherwise.

The $\mathrm{Cl}^{-}$concentration (Fig. 7a) is highest at the lowest station, with a maximum mean value in winter (2180 $\left.\pm 1870 \mu \mathrm{g} \mathrm{L}^{-1}\right)$, but it decreases quickly in the first altitude step $(700-1700 \mathrm{~m})$. In the second step, the concentration decrease with altitude is less marked. The seasonal pattern 

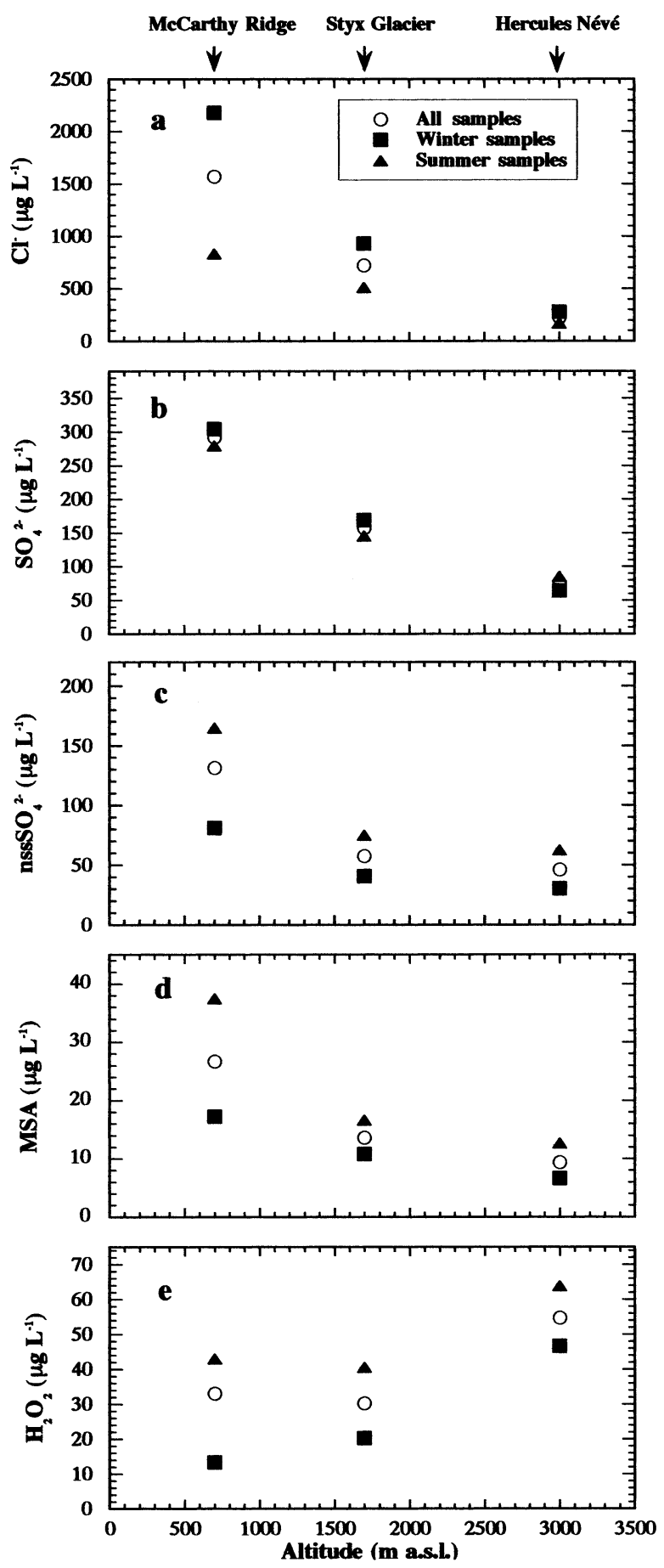

Fig. 7. Concentration trends with the altitude and the seasonality of $\mathrm{Cl}$ (a), total $\mathrm{SO}_{4}{ }^{2-}(\mathrm{b}), \mathrm{nsSSO}_{4}{ }^{2-}$ (c), MSA (d) and $\mathrm{H}_{2} \mathrm{O}_{2}(e)$ for the three firn cores.

shows a similar trend: the mean concentrations vary a lot with seasonality (winter maximum) at McCarthy, but such differences gradually decrease when the altitude increases. At Hercules Névé station (3000 m a.s.l.), a seasonal trend of the mean values is lacking, although the $\mathrm{Cl}^{-}$spikes occur mainly in winter (Fig. 3). By contrast, $\mathrm{nssSO}_{4}{ }^{2-}$ concentrations (Fig. 7c) are higher in summer at all stations, and the decrease with increasing altitude is more gradual. For the two higher stations, the mean concentrations (total, summer and winter) are very similar (around $50 \mu \mathrm{g} \mathrm{L}^{-1}$ ), showing similar seasonal patterns. From the comparison between the $\mathrm{Cl}^{-}$and $\mathrm{nsSSO}_{4}{ }^{2-}$ patterns, an altitude-induced fractionation effect is evident. This is due to the different decreasing trends: as the altitude increases, the secondary marine aerosol (biogenic source) becomes progressively more important than the sea-spray contribution. $\operatorname{totSO}_{4}{ }^{2-}$ (Fig. 7b) shows a trend which combines the $\mathrm{Cl}^{-}$and $\mathrm{nssSO}_{4}{ }^{2-}$ patterns. In fact, both sources (sea spray and biogenic marine) are important for this component, and they have contrasting seasonal patterns. So the mean tot $\mathrm{SO}_{4}{ }^{2-}$ concentration values show a decrease with increasing altitude similar to that of $\mathrm{Cl}^{-}$, and their seasonal variation is very low, because the winter seaspray maxima are counterbalanced by summer maxima of the biogenic contribution. It is interesting to note that at the lowest station the seasonality of sea-spray is prevalent (winter maxima), whereas at the highest station we observe higher mean concentration values in the summer (the $\mathrm{nssSO}_{4}{ }^{2-}$ contribution becomes dominant).

The decreasing trend of $\mathrm{nssSO}_{4}{ }^{2-}$ with increasing altitude and its seasonal pattern are fully confirmed by the MSA concentration trend (Fig. 7d), showing that the biogenic contribution is dominant with respect to the other sources (volcanic, crustal) for $\mathrm{nsSO}_{4}{ }^{2-}$ at coastal sites. Even at the highest station, MSA shows marked seasonal variations, with summer maxima. A sharp seasonal pattern is also shown by the $\mathrm{H}_{2} \mathrm{O}_{2}$ mean concentration profiles (Fig. 7e). Unlike the previous patterns, this component does not show a concentration decrease with altitude. This is because $\mathrm{H}_{2} \mathrm{O}_{2}$ is produced directly in the atmosphere over the whole Antarctic ice sheet, and the aerosol transport processes and their fractionating effects do not affect its atmospheric concentration levels. The $\mathrm{H}_{2} \mathrm{O}_{2}$ concentration in snow should therefore be more closely related to the accumulation rate, as is shown by its progressive increase with altitude.

The different contributions of primary and secondary marine aerosols as a function of altitude and seasonality heavily affect the snow composition. In winter, at the lowest station, the sea-spray content is $>90 \%$ of the total marine contribution. In summer, at the highest station, the secondary marine aerosol $\left(\mathrm{nsSSO}_{4}{ }^{2-}\right.$ and MSA) constitutes about $50 \%$ of the marine input. These results fully confirm those previously obtained for snow-pit samples collected at the same stations (and at another intermediate-altitude site) over a shorter time interval (Udisti and others, 1999).

\subsection{Comparison of annual accumulation rates}

Figure 8 shows the annual accumulation rates for the three sampled stations. The McCarthy firn core shows the largest annual variability, with a maximum value of $426 \mathrm{~kg} \mathrm{~m}^{-2} \mathrm{a}^{-1}$ and a minimum of $130 \mathrm{~kg} \mathrm{~m}^{-2} \mathrm{a}^{-1}$ annual accumulation rates at Styx Glacier plateau are $111-335 \mathrm{~kg} \mathrm{~m}^{-2} \mathrm{a}^{-1}$, and the Hercules Névé station shows the lowest annual changes, $83-264 \mathrm{~kg} \mathrm{~m}^{-2} \mathrm{a}^{-1}$. Although the dating of each firn core is subject to an uncertainty of $10 \%$, some observations can be made from the comparison of the annual accumulation trends. A very good correlation is shown among all the firn cores in the years before 1983. We can recognize years characterized by high snow accumulation (1982, 1981, 1979, 1977, $1973)$ and drier years $(1980,1978,1974)$. For the upper part of the firn cores, the correlation is less evident, but we must also consider that in this part we also find the main uncertainties in the firn-core dating. From visual observation of the annual trends at the Styx Glacier and Hercules Névé stations, 1991 and 1990 are also characterized by high snowaccumulation rates. This result may be confirmed by the field observation of the high summer snow precipitations during the Italian Antarctic Campaigns 1990/91 and 1991/92 at Terra Nova Bay. 

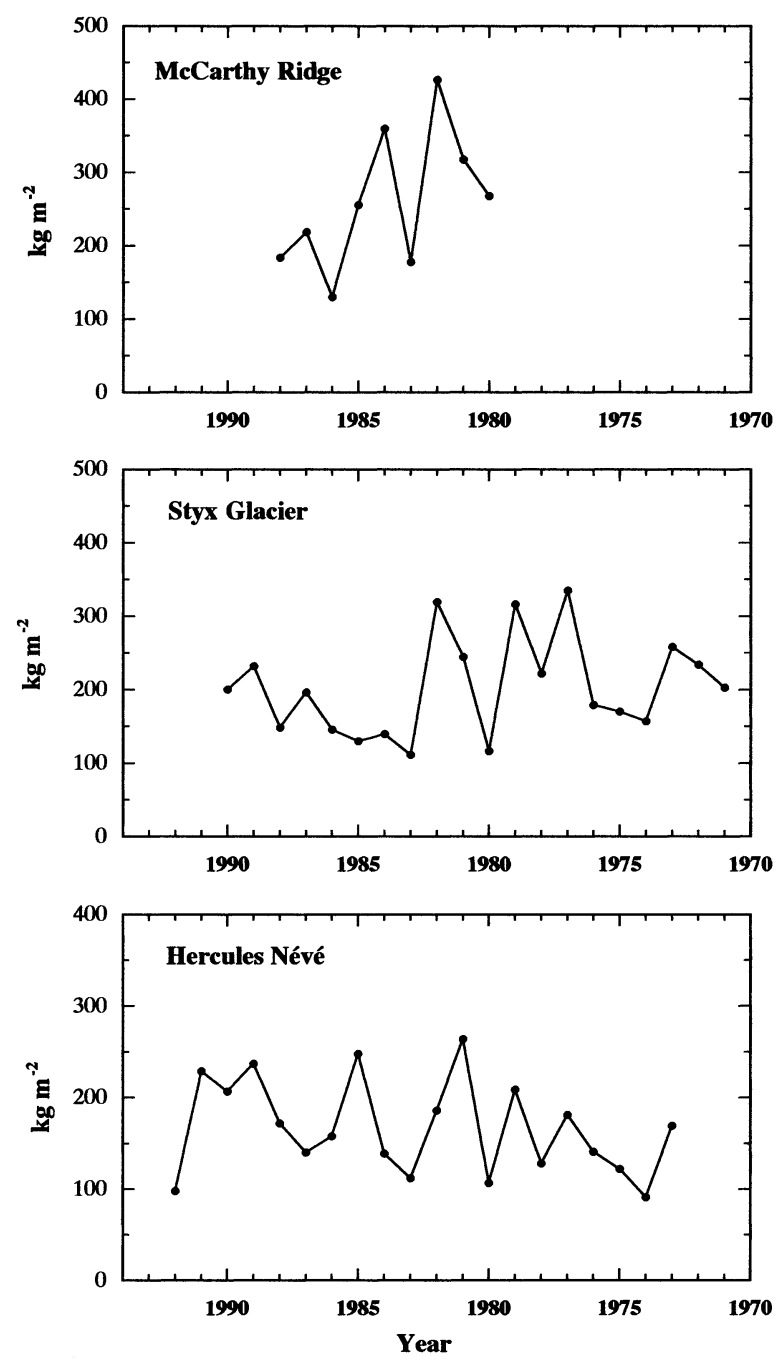

Fig. 8. Annual accumulation trends $\left(\mathrm{kg} \mathrm{m}^{-2} \mathrm{a}^{-1}\right)$ for the three sampled stations.

The accumulation-rate distribution of all the available data for northern Victoria Land shows an overall negative correlation with altitude and distance from the coast (Table 1). The maximum values are measured at McCarthy Ridge and Aviator Glacier station, the sites closest to the coast and at the lowest elevations; low accumulation rates are measured at Hercules Névé and Priestley Névé stations, located at high altitudes and far from the sea. The geographical distribution of the accumulation rates indicates that the depositional regime may depend on the orography and the direction of the storm. The E10 site, studied by Allen and others (1985), shows anomalously low accumulation values, probably because of local effects. For the northern Victoria Land area ( $\mathrm{D}^{\prime \prime}-\mathrm{D}^{\prime}$ drainage system), Giovinetto and Bentley (1985) and Vaughan and others (1999) reported net surface accumulation rates on grounded ice of 260 and $188 \mathrm{~kg} \mathrm{~m}^{-2}$ $\mathrm{a}^{-1}$, respectively. The improved estimation of $170 \mathrm{~kg} \mathrm{~m}^{-2} \mathrm{a}^{-1}$, calculated as the mean value of the data shown in Table 1 , represents a decrease of $35 \%$ and $10 \%$ with respect to previous estimations. Frezzotti (1997) estimated a $24.8 \pm 9.5 \mathrm{Gt} \mathrm{a}^{-1}$ ice discharge for the glaciers of northern Victoria Land $\left(\mathrm{D}^{\prime \prime}-\mathrm{D}^{\prime}\right.$ drainage system). By comparing these data to Giovinetto and Bentley's (1985) accumulation value of $40.9 \pm 20 \% \mathrm{Gta}^{-1}$, Frezzotti (1997) suggested a combined positive mass balance of these glaciers due to the $40 \%$ surplus of snow accumulation. Considering the estimated ice-discharge rate of 24.8 $\pm 9.5 \mathrm{Gta}^{-1}$ for the $\mathrm{D}^{\prime \prime}-\mathrm{D}^{\prime}$ drainage system $\left(148000 \mathrm{~km}^{2}\right)$ and assuming a steady state, a surface snow-accumulation balance of $167 \mathrm{~kg} \mathrm{~m}^{-2} \mathrm{a}^{-1}$ is calculated. This is very close to the net surface accumulation rate of $170 \mathrm{~kg} \mathrm{~m}^{-2} \mathrm{a}^{-1}$ calculated in this paper. The difference between our results and previous ones may result from overestimation of snow accumulations due to the use of historical data from snow-pit stratigraphy, as suggested by Frezzotti and others (2000) for eastern Dome C.

\subsection{Stable-isotope/temperature relationship}

Linear relationships between $\delta^{18} \mathrm{O}$ and the mean annual surface temperature at the sampling site $(\delta / T)$ have been observed for different regions of Antarctica (Lorius and Merlivat, 1977; Peel and Clausen, 1982; Peel and others, 1988; Qin and others, 1994). In a general way, the geographical dependence of this relationship relies mainly on the difference in the local climatological situations and in the moisture of the source regions supplying the precipitations over the different Antarctic areas. Recently, the use of the $\delta / T$ relationship to correlate the ice-core isotopic profiles to the past temperature variations has been partly questioned, mainly regarding the Greenland ice sheet, because of the different spatial and temporal patterns of such a relationship (see Jouzel and others, 1997, for a comprehensive discussion). However, Jouzel and others (1997) suggested that $>70 \%$ of the isotopic changes observed in the ice-core records are explained by temperature changes alone. Therefore, better knowledge of $\delta^{18} \mathrm{O}$ distribution in the Antarctic ice sheet is needed in order to obtain a database that can be used to validate isotopic models (both Rayleigh-type distillation and general circulation models). The spatial $\delta / T$ relationship obtained in this paper for northern Victoria Land is shown in Figure 9. We used all the mean $\delta^{18} \mathrm{O}$ values obtained from the shallow firn cores drilled up to now in this area in the framework of the Italian Antarctic Project (Stenni, 1999), and the mean surface temperatures reported in Table 1 . A fairly good correlation $(R=0.90)$ can be observed, with a $\delta / T$ gradient of $0.81 \%{ }^{\circ} \mathrm{C}^{-1}$. This value is slightly higher than the Lorius and Merlivat (1977) gradient of $0.75 \%{ }^{\circ} \mathrm{C}^{-1}$, found in Terre Adélie along the Dumont d'Urville and Dome $\mathrm{C}$ traverse, and generally used in East Antarctica. The Lorius and Merlivat (1977) regression line is reported in Figure 9, for comparison. The slight difference between the two lines could be due to the different climatic conditions of the oceanic source regions delivering moisture to the Antarctic continent, as suggested by Qin and others (1994) and Stenberg and others (1998). We must also bear in mind that the northern Victoria Land sites are located at higher latitudes than those described by the Lorius and Merlivat equation. Moreover, the northernVictoria Land area examined here is more mountainous, with sub-adiabatic lapse rate $\left(0.5^{\circ} \mathrm{C}(100 \mathrm{~m})^{-1}\right)$, whereas the plateau area studied by Lorius and Merlivat (1977) has a near-dry-adiabatic lapse rate $\left(1.1^{\circ} \mathrm{C}(100 \mathrm{~m})^{-1}\right)$.

We suggest that the northernVictoria Land region could be more influenced by the Pacific Ocean sector and, on a regional scale, by the nearby Ross Sea. The annual cycle of the sea ice in the Ross Sea may play a role in the isotopic composition changes of snow precipitations. If part of the air-mass cooling occurs over the sea ice, a more isotopically depleted water vapour will reach the coast. In fact, the new regression line (Fig. 9) is shifted toward lower $\delta^{18} \mathrm{O}$ values than the Lorius and Merlivat one. Indeed, isobaric cooling of air masses over sea ice would lead to precipitations with 


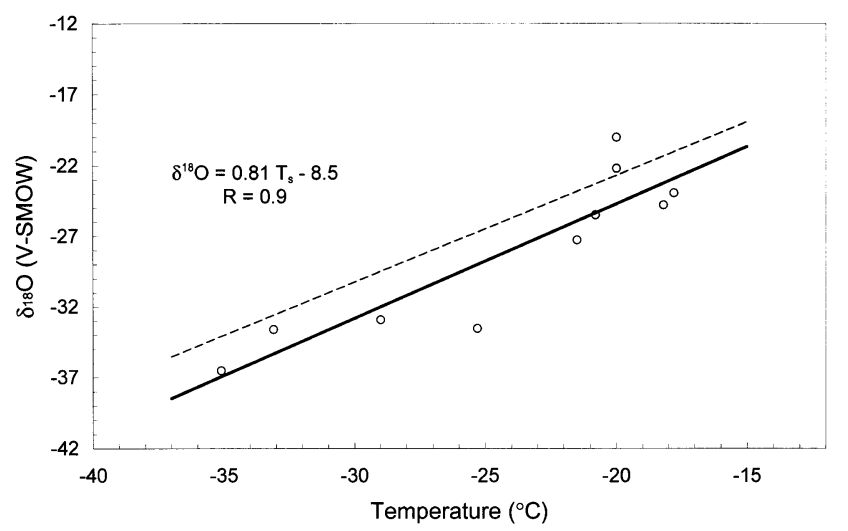

Fig. 9. Least-squares regression between $\delta^{18} O$ and temperature for firn cores drilled in northern Victoria Land. The dashed line refers to the Lorius and Merlivat (1977) equation.

higher $\delta / T$ gradients than adiabatically cooled air masses (Dansgaard, 1964).

\section{GONCLUSIONS}

This study underlines the importance of a multiparametric approach in order to date ice cores from such a meteorologically and topographically variable area as the coastal region of northern Victoria Land. The use of several seasonal markers reduces the likelihood of mistakes due to singular events that can affect an individual parameter. The comparison between the $\delta^{18} \mathrm{O}$ profile and a composite chemical profile (normalized sum of $\mathrm{H}_{2} \mathrm{O}_{2}, \mathrm{nssSO}_{4}{ }^{2-}$ and MSA) has given good results for summer peak identification. The seasonal signal of the parameters used for dating was very sharp, even for the highest station (Hercules Névé; $3000 \mathrm{~m}$ a.s.l.), because of its relatively high mean accumulation rate.

As expected, the mean accumulation rates show a sharp decrease from the coast $\left(260 \mathrm{~kg} \mathrm{~m}^{-2} \mathrm{a}^{-1}\right)$ to the margin of the Antarctic Plateau $\left(159 \mathrm{~kg} \mathrm{~m}^{-2} \mathrm{a}^{-1}\right)$. This difference can be principally attributed to the different altitudes. Altitude is also a fundamental parameter for controlling the chemical composition of snow precipitations, especially for the sea-spray and marine biogenic components. In fact, altitude-induced aerosol-fractionating processes change the absolute and relative contributions of the two marine sources.

The accumulation values are in good agreement with those obtained from snow pits and firn cores sampled in the same area. The mean accumulation value for all the available data $\left(170 \mathrm{~kg} \mathrm{~m}^{-2} \mathrm{a}^{-1}\right)$ leads to an improvement of the previous estimations for the northern Victoria Land region. The new value is very close to that required for a zero net surface mass balance according to ice discharge.

A linear relationship between the mean $\delta^{18} \mathrm{O}$ values and the mean annual surface temperatures gave a $\delta / T$ gradient of $0.81 \%{ }^{\circ} \mathrm{C}^{-1}$, slightly higher than the value of $0.75 \%{ }^{\circ} \mathrm{C}^{-1}$ previously calculated for the Terre Adélie inner regions, indicating possible different sources and transport processes of the air masses reaching the coastal area of northern Victoria Land. A better knowledge of the regional correlation between $\delta^{18} \mathrm{O}$ and surface temperature, also including more continental sites, will be possible in the future through the isotopic analysis of surface samples collected during an Italian traverse (in the framework of the International Trans-Antarctic Scientific Expedition) from Terra Nova Bay to Dome C.

\section{ACKNOWLEDGEMENTS}

Research was carried out in the framework of a Project on Glaciology and Palaeoclimatology of the Programma Nazionale di Ricerche in Antartide, and financially supported by Ente per le Nuove Tecnologie, Energia e l'Ambiente (ENEA) through a cooperation agreement with Università degli Studi di Milano.

\section{REFERENCES}

Allen, B., III, P. A. Mayewski, W. B. Lyons and M. J. Spencer. 1985. Glaciochemical studies and estimated net mass balances for Rennick Glacier area, Antarctica. Ann. Glaciol., 7, 1-6.

Ayers, G. P. and J. L. Gras. 1991. Seasonal relationship between cloud condensation nuclei and aerosol methanesulphonate in marine air. Nature, 353(6347), 834-835.

Ayers, G. P., J. P. Ivey and R.W. Gillet. 1991. Coherence between seasonal cycles of dimethyl sulphide, methanesulphonate and sulphate in marine air. Nature, 349(6308), 404-406.

Bromwich, D. H. and D. D. Kurtz. 1984. Katabatic wind forcing of the Terra Nova Bay polynya. 7. Geophys. Res., 89(C3), 3561-3572.

Bromwich, D. H. and C. J. Weaver. 1983. Latitudinal displacement from main moisture source controls $\delta^{18} \mathrm{O}$ of snow in coastal Antarctica. Nature, 301 (5896), 145-147.

Caprioli, R. and 7 others. 1998. Stratigraphic, isotopic and chemical profiles of a firn core from Drygalski ice tongue and a snow pit from Aviator Glacier (northern Victoria Land, Antarctica). Terra Antartica Rep. 1, 1997, 71-76.

Dansgaard, W. 1964. Stable isotopes in precipitation. Tellus, 16(4), 436-468.

Dansgaard, W. and 10 others. 1993. Evidence for general instability of past climate from a 250-kyr ice-core record. Nature, 364(6434), 218-220.

Delmas, R. J. 1986. Antarctic precipitation chemistry. In Jaeschke, W., ed. Chemistry of multiphase atmospheric systems. Berlin, etc., Springer-Verlag, 249-266. (NATO ASI Series G: Ecological Sciences 6.)

Delmas, R. J. 1994. Ice records of the past environment. Sci. Total Environ., $143(1), 17-30$.

De Mora, S. J., D. J. Wylie and A.L. Dick. 1997. Methanesulphonate and non-sea-salt sulphate in aerosol, snow and ice on the East Antarctic plateau. Antarct. Sci., 9(1), 46-55.

Duphorn, K. 1981. Physiographical and glaciogeological observations in north Victoria Land, Antarctica. Geol. Fahrb., Ser. B 41, 89-109.

Epstein, S. and T. Mayeda. 1953. Variation of $\mathrm{O}^{18}$ content of waters from natural sources. Geochim. Cosmochim. Acta, 4(5), 213-224.

Frezzotti, M. 1993. Glaciological study in Terra Nova Bay, Antarctica, inferred from remote sensing analysis. Ann. Glaciol., 17, 63-71.

Frezzotti, M. 1997. Ice front fluctuation, iceberg calving flux and mass balance of Victoria Land glaciers. Antarct. Sci., 9(1), 61-73.

Frezzotti, M. 1998. Surface wind field of Victoria Land (Antarctica) from surveys of aeolian morphologic features. Terra Antartica Rep. 1, 1997, 43-45.

Frezzotti, M., I.E. Tabacco and A. Zirizzotti. 2000. Ice discharge of eastern Dome $\mathrm{C}$ drainage area, Antarctica, inferred from airborne radar survey and satellite image analysis. F. Glaciol., 46(153), 253-264.

Giovinetto, M. B. and C. R. Bentley. 1985. Surface balance in ice drainage systems of Antarctica. Antarct. F. U.S., 20(4), 6-13.

Gonfiantini, R. 1978. Standards for stable isotope measurements in natural compounds. Nature, 271 (5645), 534.

Goodwin, I. D. 1990. Snow accumulation and surface topography in the katabatic zone of eastern Wilkes Land, Antarctica. Antarct. Sci., 2(3), 235-242.

Goodwin, I. D. 1991. Snow-accumulation variability from seasonal surface observations and firn-core stratigraphy, eastern Wilkes Land, Antarctica. f. Glaciol., 37(127), 383-387.

Gragnani, R., C. Smiraglia, B. Stenni and S. Torcini. 1998. Chemical and isotopic profiles from snow pits and shallow firn cores on Campbell Glacier, northern Victoria Land, Antarctica. Ann. Glaciol., 27, 679-684.

Hawley, M. E., J. N. Galloway and W.C. Keene. 1988. Standard error calculations for non sea salt constituents in marine precipitation. Water, Air, Soil Pollut., 42(1-2), 87-102.

Hwang, H. and P. K. Dasgupta. 1985. Fluorimetric determination of trace hydrogen peroxide in water with a flow injection system. Anal. Chim. Acta, 170, 347-352.

Isaksson, E. and W. Karlén. 1994. High resolution climatic information from short firn cores, western Dronning Maud Land, Antarctica. Climatic Change, 26(4), 421-434.

Johnsen, S. J. 1977. Stable isotope homogenization of polar firn and ice. International Association of Hydrological Sciences Publication 118 (Symposium at Grenoble 1975 - Isotopes and Impurities in Snow and Ice ), 210-219. 
Jouzel, J. and 16 others. 1993. Extending the Vostok ice-core record of palaeoclimate to the penultimate glacial period. Nature, 364(6436), 407-411.

Jouzel, J. and 12 others. 1997. On the validity of the temperature reconstruction from water isotopes in ice cores. F. Geophys. Res., 102(Cl2), 26,471-26,487.

Keene, W. C., A. A. P. Pszenny, J. N. Galloway and M. E. Hawley. 1986. Sea-salt corrections and interpretation of constituent ratios in marine precipitation. 7. Geophys. Res., 91(D6), 6647-6658.

Kuhn, M. 1970. Ice crystals and solar halo displays, Plateau Station, 1967. International Association of Scientific Hydrology Publication 86 (Symposium at Hanover 1968 - Antartic Glaciological Exploration (ISAGE) ), 298-303.

Langway, C.C., Jr, K. Osada, H. B. Clausen, C. U. Hammer, H. Shoji and A. Mitani. 1994. New chemical stratigraphy over the last millennium for Byrd Station, Antarctica. Tellus, 46B (1), 40-51.

Legrand, M. 1995. Sulphur-derived species in polar ice: a review. In Delmas, R. J., ed. Ice core studies of global biogeochemical cycles. Berlin, etc., SpringerVerlag, 91-119. (NATO ASI Series I: Global Environmental Change 30.)

Legrand, M. and C. Saigne. 1988. Formate, acetate and methanesulfonate measurements in Antarctic ice: some geochemical implications. Atmos. Environ., 22(5), 1011-1017.

Legrand, M., R. J. Delmas and R. J. Charlson. 1988. Climate forcing implications from Vostok ice-core sulphate data. Nature, 334(6181), 418-420.

Legrand, M., C. Feniet-Saigne, E. S. Saltzman, C. Germain, N. I. Barkov and V. N. Petrov. 1991. Ice-core record of oceanic emissions of dimethylsulphide during the last climate cycle. Nature, 350(6314), 144-146.

Lorius, C. and L. Merlivat. 1977. Distribution of mean surface stable isotope values in East Antarctica: observed changes with depth in the coastal area. International Association of Hydrological Sciences Publication 118 (Symposium at Grenoble 1975 - Isotopes and Impurities in Snow and Ice), 127-137.

Lyon, G. L. 1986. Stable isotope stratigraphy of ice cores and the age of the last eruption at Mount Melbourne, Antarctica. N.Z. F. Geol. Geophys., $29(1), 135-138$.

Maggi, V. and 8 others. 1998.70 years of northern Victoria Land (Antarctica) accumulation rate. Ann. Glaciol., 27, 215-219.

Maupetit, F. and R. J. Delmas. 1992. Chemical composition of falling snow at Dumont d'Urville, Antarctica. F. Atmos. Chem., 14(1), 31-42.

Merlivat, L. and J. Jouzel. 1979. Global climatic interpretation of the deuterium-oxygen 18 relationship for precipitation. 7. Geophys. Res., 84(C8), 5029-5033.

Minikin, A., D. Wagenbach, W. Graf and J. Kipfstuhl. 1994. Spatial and seasonal variations of the snow chemistry at the central Filchner-Ronne Ice Shelf, Antarctica. Ann. Glaciol., 20, 283-290.

Mosley-Thompson, E., J. Dai, L. G. Thompson, P. M. Grootes, J. K. Arbogast and J. F. Paskievitch. 1991. Glaciological studies at Siple Station (Antarctica): potential ice-core paleoclimatic record. F. Glaciol., 37(125), 11-22.

Mullan, A. B. and M. R. Sinclair. 1990. Climate and weather. In Hatherton, T., ed. Antartica: the Ross Sea region. Wellington, New Zealand, DSIR Publishing, 98-115. (DSIR Information Series 165.)

Mulvaney, R., E. C. Pasteur, D. A. Peel, E. S. Saltzman and P.-Y. Whung. 1992. The ratio of MSA to non-sea-salt sulphate in Antarctic Peninsula ice cores. Tellus, 44B (4), 295-303.

Mulvaney, R., G. F. J. Coulson and H. F. J. Corr. 1993. The fractionation of sea salt and acids during transport across an Antarctic ice shelf. Tellus, 45B (2), 179-187.

Neftel, A. 1991. Use of snow and firn analysis to reconstruct past atmospheric composition. In Davies, T. D., M. Tranter and H. G. Jones, eds. Seasonal snowpacks: processes of compositional change. Berlin, etc., Springer-Verlag, 385-415. (NATO ASI Series G: Ecological Sciences 28.)

Neftel, A. and K. Fuhrer. 1993. A record of atmospheric oxidant from polar ice cores over the past 100,000 years: dream or real possibility? In Niki, H. and K. H. Becker, eds. The tropospheric chemistry of ozone in the polar regions. Berlin, etc., Springer-Verlag, 219-233. (NATO ASI Series I: Global Environmental Change 7.)

Peel, D. A. and H. B. Clausen. 1982. Oxygen-isotope and total beta-radioactivity measurements on $10 \mathrm{~m}$ ice cores from the Antarctic Peninsula. 7. Glaciol., 28(98), 43-55.

Peel, D. A., R. Mulvaney and B. M. Davison. 1988. Stable-isotope/air-temperature relationships in ice cores from Dolleman Island and the Palmer Land plateau, Antarctic Peninsula. Ann. Glaciol., 10, 130-136.

Petit, J.-R. and 18 others. 1999. Climate and atmospheric history of the past 420,000 years from the Vostok ice core, Antarctica. Nature, 399(6735), 429-436.

Pettré, P., J. F. Pinglot, M. Pourchet and L. Reynaud. 1986. Accumulation distribution in Terre Adélie, Antarctica: effect of meteorological parameters. F. Glaciol., 32(112), 486-500.

Piccardi, G., R. Udisti and F. Casella. 1994a. Seasonal trends and chemical composition of snow at Terra Nova Bay (Antarctica). Int. F. Environ. Anal.
Chem., 55, 219-234.

Piccardi, G., E. Barbolani, S. Bellandi, F. Casella and R. Udisti. 1994b. Spatial and temporal trends of snow chemical composition of northern Victoria Land (Antarctica). Terra Antartica 1, 134-137.

Piccardi, G., S. Becagli, R. Traversi and R. Udisti. 1996a. Fractionating phenomena, altitude induced, on snow composition in northern Victoria Land (Antarctica). In Colacino, M., G. Giovannelli and L. Stefanutti, eds. Conference on Italian Research on Antarctic Atmosphere, 6-8 November 1995, Florence, Italy. Proceedings. Vol. 51. Bologna, Società Italiana di Fisica, 229-245.

Piccardi, G., F. Casella and R. Udisti. 1996b. Non-sea-salt contribution of some chemical species to the snow composition at Terra Nova Bay (Antarctica). Int. F. Environ. Anal. Chem., 63, 207-223.

Qin Dahe, J. R. Petit, J. Jouzel and M. Stievenard. 1994. Distribution of stable isotopes in surface snow along the route of the 1990 International Trans-Antarctica Expedition. F. Glaciol., 40(134), 107-118.

Rossi, A. 1991. Preliminary survey of the underground thermal regime in the area around Terra Nova Bay, Victoria Land, Antarctica. Mem. Soc. Geol. Ital., 46, 1989, 457-461.

Saltzman, E.S. 1995. Ocean/atmosphere cycling of dimethylsulfide. In Delmas, R. J., ed. Ice core studies of global biogeochemical cycles. Berlin, etc., SpringerVerlag, 65-90. (NATO ASI Series I: Global Environmental Change 30.)

Saltzman, E. S., D. L. Savoie, R. G. Zika and J. M. Prospero. 1983. Methane sulfonic acid in the marine atmosphere. F. Geophys. Res., 88 (Cl5), 10,897-10,902.

Saltzman, E. S., D. L. Savoie, J. M. Prospero and R. G. Zika. 1986. Methanesulphonic acid and non-sea-salt sulphate in Pacific air: regional and seasonal variations. F. Atmos. Chem., 4, 227-240.

Savoie, D. L. and J. M. Prospero. 1989. Comparison of oceanic and continental sources of non-sea-salt sulphate over the Pacific Ocean. Nature, 339 (6227), 685-687.

Shaw, G. E. 1988. Antarctic aerosols: a review. Rev. Geophys., 26 (1), 89-112.

Sigg, A., T. Staffelbach and A. Neftel. 1992. Gas phase measurements of hydrogen peroxide in Greenland and their meaning for the interpretation of $\mathrm{H}_{2} \mathrm{O}_{2}$ records in ice cores. F. Atmos. Chem., 14 (1-4), 223-232.

Steig, E. J., P. M. Grootes and M. Stuiver. 1994. Seasonal precipitation timing and ice core records. Science, 266(5192), 1885-1886.

Stenberg, M. and 7 others. 1998. Spatial variability of snow chemistry in western Dronning Maud Land, Antarctica. Ann. Glaciol., 27, 378-384.

Stenni, B. 1999. Ricostruzione paleoclimatica basata sulla stratigrafia isotopica di carote di nevato-ghiaccio nella Terra Vittoria settentrionale (Antartide). (Ph.D. thesis, University of Milano.)

Stenni, B. and 8 others. 1999. 200 years of isotope and chemical records in a firn core from Hercules Névé, northern Victoria Land, Antarctica. Ann. Glaciol., 29, 106-112.

Stuart, A.W. and A. J. Heine. 1961. Glaciological work of the 1959-60 U.S. Victoria Land traverse. 7. Glaciol., 3(30), 997-1002.

Udisti, R. 1996. Multiparametric approach for chemical dating of snow layers from Antarctica. Int. F. Environ. Anal. Chem., 63, 225-244.

Udisti, R., F. Casella and G. Piccardi. 1993. The role of methanesulphonic acid in snow samples from Terra Nova Bay (Antarctica). In Restelli, G. and G. Angeletti, eds. Dimethylsulphide: oceans, atmosphere and climate. Dordrecht, etc., Kluwer Academic Publishers, 153-162. (Air Pollution Research Report 43.)

Udisti, R., S. Bellandi and G. Piccardi. 1994. Analysis of snow from Antarctica: a critical approach to ion-chromatographic methods. Fresenius' $\mathcal{F}$. Anal. Chem., 349(4), 289-293.

Udisti, R., S. Becagli, R. Traversi, S. Vermigli and G. Piccardi. 1998a. Preliminary evidence of a biomass-burning event from a 60 year-old firn core from Antarctica by ion chromatographic determination of carboxylic acids. Ann. Glaciol., 27, 391-397.

Udisti, R., R. Traversi, S. Becagli and G. Piccardi. 1998b. Spatial distribution and seasonal pattern of biogenic sulphur compounds in snow from northern Victoria Land, Antarctica. Ann. Glaciol., 27, 535-542.

Udisti, R., S. Becagli, E. Castellano, R. Traversi, S. Vermigli and G. Piccardi. 1999. Sea-spray and marine biogenic seasonal contribution to snow composition at Terra Nova Bay, Antarctica. Ann. Glaciol., 29, 77-83.

Vaughan, D. G., J. L. Bamber, M. B. Giovinetto, J. Russell and A. P. R. Cooper. 1999. Reassessment of net surface mass balance in Antarctica. 7. Climate, 12(4), 933-946.

Wagenbach, D. 1996. Coastal Antarctica: atmospheric chemical composition and atmospheric transport. In Wolff, E.W. and R. C. Bales, eds. Chemical exchange between the atmosphere and polar snow. Berlin, etc., Springer-Verlag, 173-199. (NATO ASI Series I: Global Environmental Change 43.)

Wagenbach, D. and 7 others. 1998. Sea-salt aerosol in coastal Antarctic regions. 7. Geophys. Res., 103(D9), 10,961-10,974.

Watanabe, O. 1978. Distribution of surface features of snow cover in Mizuho Plateau. Mem. Natl. Inst. Polar Res., Special Issue 7, 44-62. 